Supporting Information

\title{
One-Pot Chemo-Enzymatic Conversion of Alkynes to Chiral Amines
}

\author{
Sam Mathew ${ }^{\dagger \S}$, Arunachalam Sagadevan ${ }^{\dagger \S}$, Dominik Renn ${ }^{\dagger \ddagger}$, Magnus Rueping ${ }^{\dagger \ddagger *}$ \\ tKAUST Catalysis Center (KCC), King Abdullah University of Science and Technology (KAUST), Thuwal, \\ 23955-6900 (Saudi Arabia) \\ ¥Institute for Molecular Imaging, RWTH Aachen, Forckenbeckstrasse 55, 52074 (Germany) \\ $\S$ These authors contributed equally. \\ *Corresponding author: magnus.rueping@Kaust.edu.sa
}

\section{Table of contents}

1. Materials

2. General procedure

2.1 Gold mediated reactions

2.2 Enzymatic reactions

2.3 Sample preparation

3. Analytical methods

4. Amine-transaminase screening

5. Chiral HPLC analysis

5.1 Chromatograms

5.2 HPLC standard curves of amine products

6. NMR-spectroscopic data \& spectra

7. References 


\section{Materials}

General: The alkyne starting materials; 3a, 5a, 6a, and 9a were purchased from Tokyo Chemical Industry $(\mathrm{TCl})$. All other chemicals and solvents were purchased from Sigma-Aldrich. Codex ${ }^{\circledR}$ Amine Transaminase (ATA) Screening Kit and PLP were purchased from Codexis.

Compounds (1c \& 7c) were purified by column chromatography by using Interchim PuriFlash $\AA_{215}$ automatic purification system. Furthermore, compounds (1c \& 7c) were characterized by ${ }^{1} \mathrm{H}$ NMR, ${ }^{13} \mathrm{C}$ NMR spectroscopy. ${ }^{1} \mathrm{H},{ }^{13} \mathrm{C}$ NMR spectra were recorded at $298 \mathrm{~K}$ on $500 \mathrm{MHz}$ Bruker NMR spectrometers as stated. Signal positions were recorded in $\delta \mathrm{ppm}$ and measured from the centre of the signal, excluding multiples, which are given as a range. Splitting patterns are reported using the abbreviations $\mathrm{s}, \mathrm{br}, \mathrm{s}, \mathrm{d}, \mathrm{t}, \mathrm{q}$, quin, sept, and $\mathrm{m}$ (or combinations thereof) denoting singlet, broad singlet, doublet, triplet, quartet, quintet, septet, and multiplet respectively. All ${ }^{1} \mathrm{H} \mathrm{NMR}$ and ${ }^{13} \mathrm{C}$ chemical shifts were referenced to the residual solvent peak of $\mathrm{CDCl}_{3}$ ( ${ }^{1} \mathrm{H}$ referenced to $7.26 \mathrm{ppm}$ and ${ }^{13} \mathrm{C}$ referenced to $77.16 \mathrm{ppm}$ ). All coupling constants, J, are quoted in $\mathrm{Hz}$ and reported to the nearest $0.1 \mathrm{~Hz}$ as observed in the spectra. Organic solutions were concentrated under reduced pressure on a Büchi rotary evaporator.

\section{General procedure}

\subsection{Gold-mediated reactions}

\section{Scheme S1}

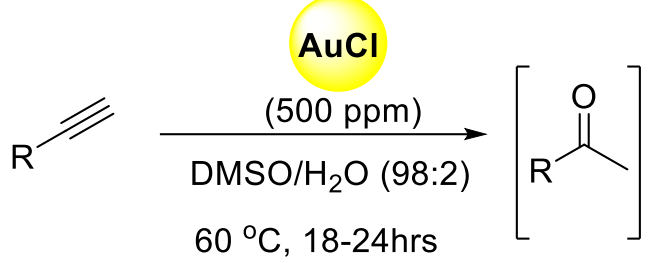

A typical gold-catalyzed conversion of alkynes to ketone: ${ }^{[1]} \mathrm{A}$ dry test tube $(10 \mathrm{~mL})$ containing 25 $\mathrm{mM}$ substrate (terminal alkynes) with $\mathrm{AuCl}\left(500 \mathrm{ppm}\right.$ ) in $1 \mathrm{~mL}$ DMSO: $\mathrm{H}_{2} \mathrm{O}$ (98:2). The reaction mixture was then stirred at $60^{\circ} \mathrm{C}$ for $18-24$ hrs until completion of the reaction (monitored by GC). After completion of the reaction, the subsequent part of the reaction mixture (without isolation and purification) was directly subjected to the transamination step. For the cascade reaction, $0.2 \mathrm{~mL}$ reactions with the above condition were performed. The preparative cascade reaction was performed on a $2 \mathrm{~mL}$ scale by using the above reaction procedure. 
Table S1. Optimization study: conversion of alkynes to ketone.

\begin{tabular}{|c|c|c|c|c|c|}
\hline Entry & $\begin{array}{c}\text { Au catalyst } \\
\text { (amount) }\end{array}$ & Solvents & $\begin{array}{l}\text { Solvent ratio } \\
\text { (Org.sol: } \mathrm{H}_{2} \mathrm{O} \text { ) }\end{array}$ & $\begin{array}{c}\text { Temperature } \\
\left({ }^{\circ} \mathrm{C}\right)\end{array}$ & $\begin{array}{l}\text { Product yield/ } \\
\text { (hour) }\end{array}$ \\
\hline 1 & $5 \mathrm{~mol} \%$ & $\mathrm{MeOH}-\mathrm{H}_{2} \mathrm{O}$ & 98:2 & 60 & $>98 \%(12 \mathrm{hr})$ \\
\hline 2 & $\begin{array}{c}0.2 \mathrm{~mol} \% \\
\text { (500 ppm) }\end{array}$ & $\mathrm{MeOH}-\mathrm{H}_{2} \mathrm{O}$ & $98: 2$ & 60 & $>98 \%$ (18hr) \\
\hline 3 & $\begin{array}{c}0.2 \mathrm{~mol} \% \\
(500 \mathrm{ppm})\end{array}$ & DMSO- $\mathrm{H}_{2} \mathrm{O}$ & 98:2 & 60 & $>98 \%$ (18hr) \\
\hline 4 & $\begin{array}{c}0.2 \mathrm{~mol} \% \\
\text { (500 ppm) }\end{array}$ & DMSO- $\mathrm{H}_{2} \mathrm{O}$ & 98:2 & 35 & $60 \%$ (72hr) \\
\hline 5 & $\begin{array}{l}0.2 \mathrm{~mol} \% \\
(500 \mathrm{ppm})\end{array}$ & DMSO- $\mathrm{H}_{2} \mathrm{O}$ & $20: 80$ & 60 & trace $(48 \mathrm{hr})$ \\
\hline 6 & $\begin{array}{l}0.2 \mathrm{~mol} \% \\
(500 \mathrm{ppm})\end{array}$ & $\mathrm{DMSO}-\mathrm{H}_{2} \mathrm{O}$ & $50: 50$ & 60 & $25 \%(48 \mathrm{hr})$ \\
\hline 7 & $\begin{array}{l}0.2 \mathrm{~mol} \% \\
\text { (500 ppm) }\end{array}$ & DMSO- $\mathrm{H}_{2} \mathrm{O}$ & $90: 10$ & 60 & $\begin{array}{c}93 \%(24 \mathrm{hr}) \\
+ \text { over-oxidized } \\
\text { by-products }\end{array}$ \\
\hline
\end{tabular}

\subsection{Enzymatic reactions}

\section{Scheme S2}

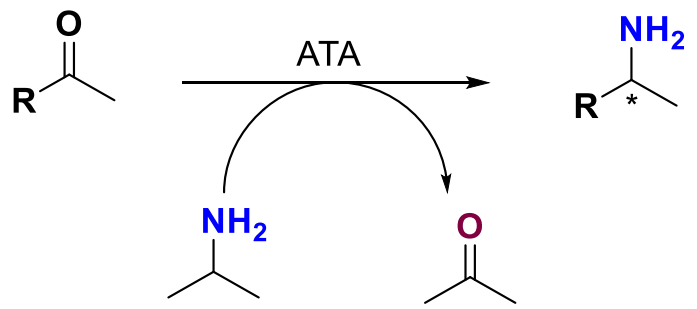

A typical enzyme reaction mixture in a $2 \mathrm{~mL}$ microtube contains $500 \mu \mathrm{L}$ of $5 \mathrm{mM}$ substrate, 50 $\mathrm{mM}$ isopropylamine, $20 \mathrm{mg} \mathrm{mL}^{-1}$ ATA, $1 \mathrm{mM} \mathrm{PLP}, 10 \%$ DMSO (v/v) in $100 \mathrm{mM}$ Tris buffer $(\mathrm{pH}$ 7.5) and was incubated at $30^{\circ} \mathrm{C}$ in a microtube shaking incubator ( $\left.300 \mathrm{rpm} \mathrm{min}{ }^{-1}\right)$ for $18-24 \mathrm{~h}$. For the ATA optimization studies, the above reactions were performed with different temperatures (30 ${ }^{\circ} \mathrm{C} / 37^{\circ} \mathrm{C} / 40^{\circ} \mathrm{C}$ ), different organic solvents (MeOH/DMSO/ACN/Tol), and different isopropylamine concentrations $(25 \mathrm{mM} / 250 \mathrm{mM} / 1500 \mathrm{mM})$. 


\section{Scheme S3}

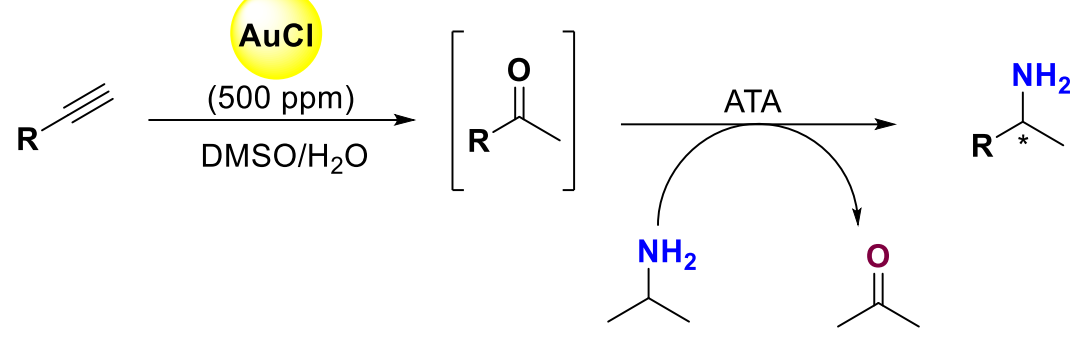

In chemo-enzymatic cascade reactions, $0.8 \mathrm{~mL}$ of the enzyme reaction mixture was added to the completed gold-catalyzed reaction mixture $(0.2 \mathrm{~mL})$. The final mixture contained $5 \mathrm{mM}$ substrate (1b-8b), $1500 \mathrm{mM}$ isopropylamine, $20 \mathrm{mg} \mathrm{mL}^{-1}$ ATA, $1 \mathrm{mM} \mathrm{PLP,} \mathrm{20 \%} \mathrm{DMSO} \mathrm{(v/v)} \mathrm{in} 100 \mathrm{mM}$ Tris buffer $(\mathrm{pH} 7.5)$ and was incubated at $30^{\circ} \mathrm{C}$ for $24 \mathrm{~h}$.

Preparative cascade reaction: In the preparative chemo-enzymatic cascade reactions (1a and 7a), $8 \mathrm{~mL}$ of the enzyme reaction mixture was added to the completed preparative scale goldcatalyzed reaction mixture $(2 \mathrm{~mL})$. The final reaction mixture contained $5 \mathrm{mM}$ substrate (ketones 1b and 7b), $1500 \mathrm{mM}$ isopropylamine, $15 \mathrm{mg} \mathrm{mL}^{-1}$ ATA, $1 \mathrm{mM}$ PLP, 20\% DMSO (v/v) in $100 \mathrm{mM}$ Tris buffer $\left(\mathrm{pH} \mathrm{7.5)}\right.$ and was incubated at $30^{\circ} \mathrm{C}$ for $24 \mathrm{hrs}$. After $24 \mathrm{hrs}$, an adequate amount of the sample was taken from the bulk reaction mixture under stirring condition, for quantifying the yield and enantiomeric excess by using the HPLC method. The bulk reaction mixture was subjected to workup by diluting with ethyl acetate $(30 \mathrm{~mL})$. The organic layer was separated by using $0.25 \mathrm{M} \mathrm{NaOH}$ aqueous solution $(20 \mathrm{~mL})$. The collected organic layer was again washed with $20 \mathrm{~mL}$ of water three times. Finally, the organic layer was concentrated by a rotary evaporator. The residue was purified by column chromatography on silica gel to collect the expected chiral amines (1c, 92\% \& 7c, 59\%), characterized by NMR spectroscopic methods and HPLC. The chiral amine yields were calculated using the HPLC method.

\subsection{Sample preparation}

After completion of the gold-catalyzed conversion of alkynes (1a-8a) to ketones (1) $\mathbf{b}-\mathbf{8} \mathbf{b})$, the reaction mixture was diluted with $4 \mathrm{~mL}$ of ethyl acetate (EA). Subsequently, the solution was filtered through a silica gell-celite bed to remove water. The collected clear organic solution would be then subjected to $\mathrm{GC}$ analysis.

For GCMS samples, $5 \mu \mathrm{L} 10 \mathrm{M} \mathrm{NaOH}$ was added to the $500 \mu \mathrm{L}$ enzymatic reaction. Subsequently, $495 \mu \mathrm{L}$ of ethyl acetate containing $5 \mathrm{mM}$ trimethyl benzene as external standard is added to the reaction mixture and vortexed. This mixture was then centrifuged at $13000 \mathrm{rpm}$ for 15 minutes 
and the $900 \mu \mathrm{L}$ from the organic layer was passed over anhydrous sodium sulfate and finally analyzed using GC-MS. The ATA screening was performed using GC-MS.

For HPLC samples, $500 \mu \mathrm{L}$ of $10 \%$ perchloric acid was added to an equal volume of the reaction mixture. The mixture was then vortexed and centrifuged at $13000 \mathrm{rpm}$ for 15 minutes. The supernatant of the centrifuged sample was then utilized for HPLC analysis.

\section{Analytical method}

The conversion of alkynes was determined by GC-FID. GC samples were analyzed on 5975C GC/MSD Series from Agilent with 19091S-413HP-5MS column (Agilent). GC program used for analyzing the samples was a 15 minutes program with the initial temperature at $75{ }^{\circ} \mathrm{C}$ for 2 minutes, then ramping $25^{\circ} \mathrm{C} \mathrm{min}-1$ to $300{ }^{\circ} \mathrm{C}$, and the final temperature was then maintained for 4 minutes. For screening ATAs, the conversion was quantified based on the depletion of acetophenone (1b) in GCMS using the same program mentioned above (Table S4). The yield and enantiomeric excess (ee) analysis of amines (Table 2) was analyzed on 1260 infinity series from Agilent with a Crownpak CR column (Daicel Co., Japan) at $210 \mathrm{~nm}$ with elution of pH 1.5 perchloric acid solution $\left(0.6 \mathrm{~mL} \mathrm{~min}{ }^{-1}\right){ }^{\left[{ }^{[2]}\right.}$ Each enantiomer was separated by these analytical conditions and running time ranged from $1 \mathrm{~h}$ to $4 \mathrm{~h}$. 
Table S2. GC analysis data: retention time of alkynes.

\begin{tabular}{|c|c|}
\hline Substrate & Retention time (min) \\
\hline $\mathbf{1 a}$ & 4.4 \\
\hline $\mathbf{2 a}$ & 4.4 \\
\hline $\mathbf{3 a}$ & 5.2 \\
\hline $\mathbf{4 a}$ & 4.1 \\
\hline $\mathbf{5 a}$ & 4.8 \\
\hline $\mathbf{6 a}$ & 5.9 \\
\hline $\mathbf{7 a}$ & 6.2 \\
\hline $\mathbf{8 a}$ & 6.0 \\
\hline
\end{tabular}

Table S3. HPLC analysis data: retention time of enantiomers of amines.

\begin{tabular}{|c|c|c|}
\hline Substrate & \multicolumn{2}{|c|}{ Retention time (min) } \\
\hline 1c & 13.5 & 18.3 \\
\hline 2c & 15.0 & 21.4 \\
\hline 3c & 37.1 & 40.8 \\
\hline 4c & 21.0 & 46.2 \\
\hline 5c & 69.3 & 81.4 \\
\hline 6c & 93.0 & 127.7 \\
\hline 7c & 18.8 & 31.5 \\
\hline 8c & 63.7 & 88.5 \\
\hline
\end{tabular}




\section{Amine-transaminase screening}

Table S4. Bio-amination of $\mathbf{1 b}$ to $1 \mathrm{c}$ using various transaminases.<smiles>CC(=O)c1ccccc1</smiles><smiles>CCCCC1CCCCC1C</smiles><smiles>CC(N)c1ccccc1</smiles><smiles>CC(C)N</smiles><smiles>CC(C)=O</smiles>

\begin{tabular}{|c|c|c|c|c|c|}
\hline Entry & Transaminase & $\begin{array}{c}\text { Conversion } \\
(\%)\end{array}$ & SNO & Transaminase & $\begin{array}{c}\text { Conversion } \\
(\%)\end{array}$ \\
\hline 1 & ATA-7 & $<1$ & 13 & ATA-254 & 59 \\
\hline 2 & ATA-13 & $<1$ & 14 & ATA-256 & 20 \\
\hline 3 & ATA-25 & 14 & 15 & ATA-260 & 58 \\
\hline 4 & ATA-113 & $<1$ & 16 & ATA-301 & $<1$ \\
\hline 5 & ATA-117 & 20 & 17 & ATA-303 & 33 \\
\hline 6 & ATA-200 & $<1$ & 18 & ATA-412 & 7 \\
\hline 7 & ATA-FO3 & 17 & 19 & ATA-415 & 49 \\
\hline 8 & ATA-217 & 15 & 20 & ATA-P2A01 & $<1$ \\
\hline 9 & ATA-234 & 8 & 21 & ATA-P2B01 & $<1$ \\
\hline 10 & ATA-237 & 49 & 22 & ATA-P1A01 & $<1$ \\
\hline 11 & ATA-238 & 8 & 23 & ATAPIG05 & 43 \\
\hline 12 & ATA-251 & 54 & 24 & ATA-B104 & 12 \\
\hline
\end{tabular}

Reaction condition: $500 \mu \mathrm{L}$ reaction volume with $\mathbf{1 b}(5 \mathrm{mM})$, isopropylamine $(50 \mathrm{mM})$, DMSO $(10 \% \mathrm{v} / \mathrm{v})$, ATA $\left(20 \mathrm{mg} \mathrm{mL}^{-1}\right)$, PLP $(1 \mathrm{mM})$, Tris- $\mathrm{HCl}(100 \mathrm{mM}, \mathrm{pH} 7.5)$ for $18 \mathrm{~h}$ at $30^{\circ} \mathrm{C}$. ATA-251: Patent EP2582799 S40. ATA-254: Patent EP2582799 S32. ATA-260: Patent WO2013139987 S46. ATA-415: Patent EP3406594 S28. 


\section{Chiral HPLC analysis}

\subsection{Chromatograms}

Chromatograms of 1c
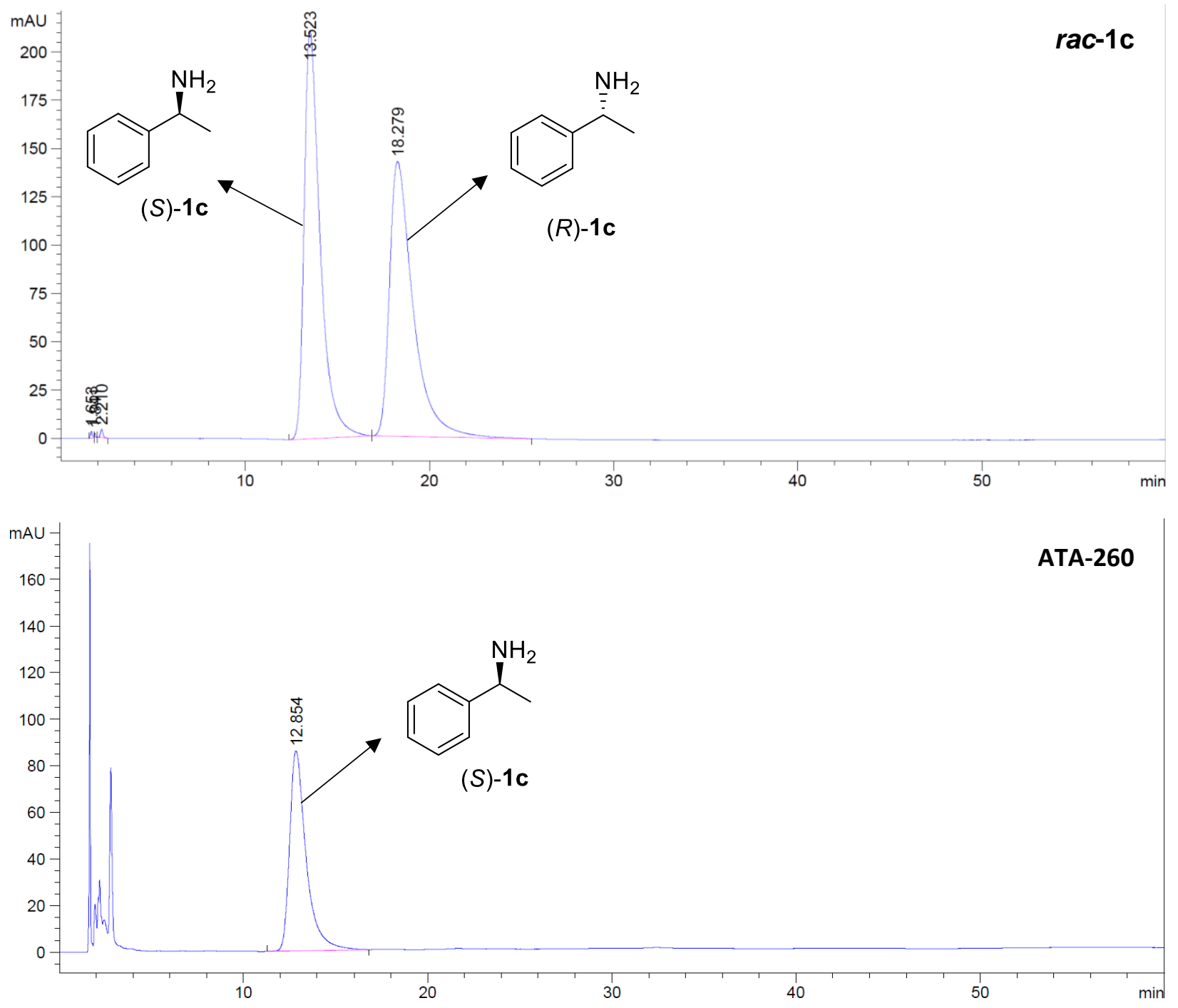


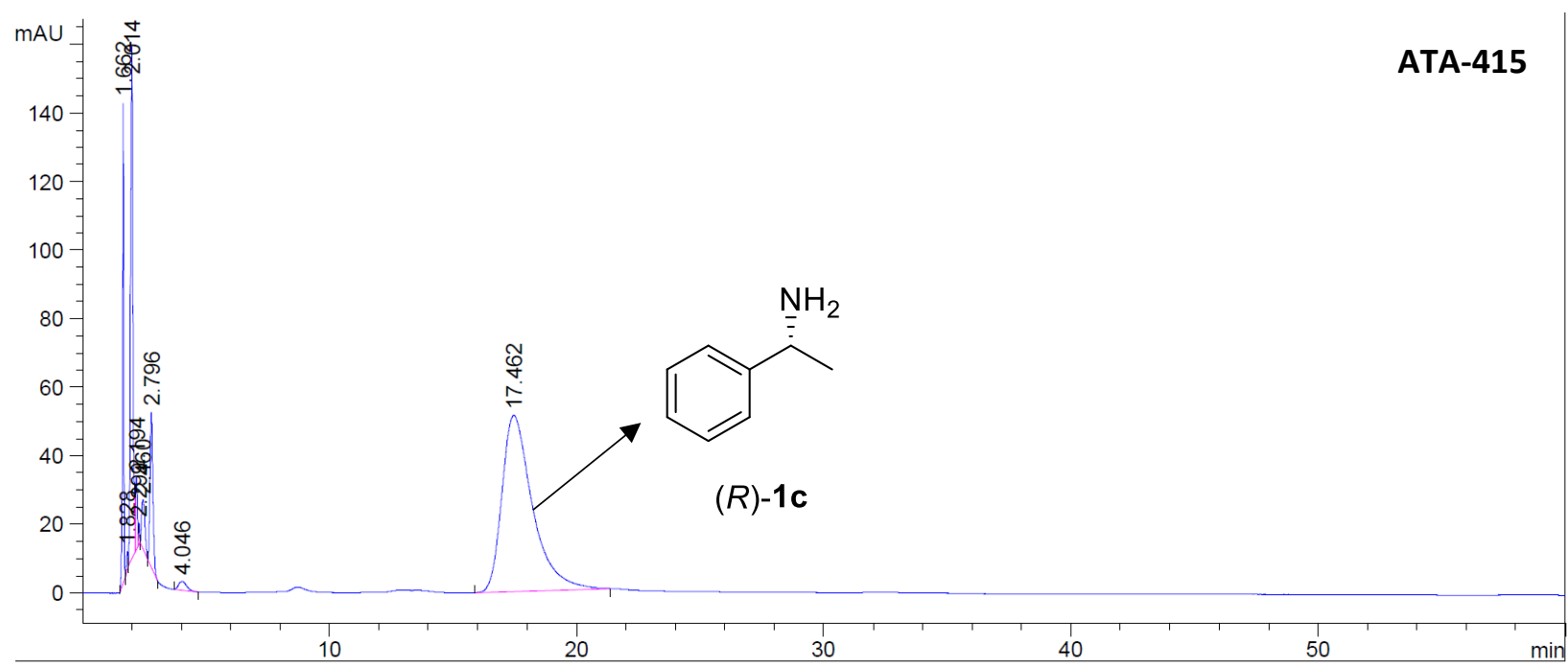

Chromatograms of 2c
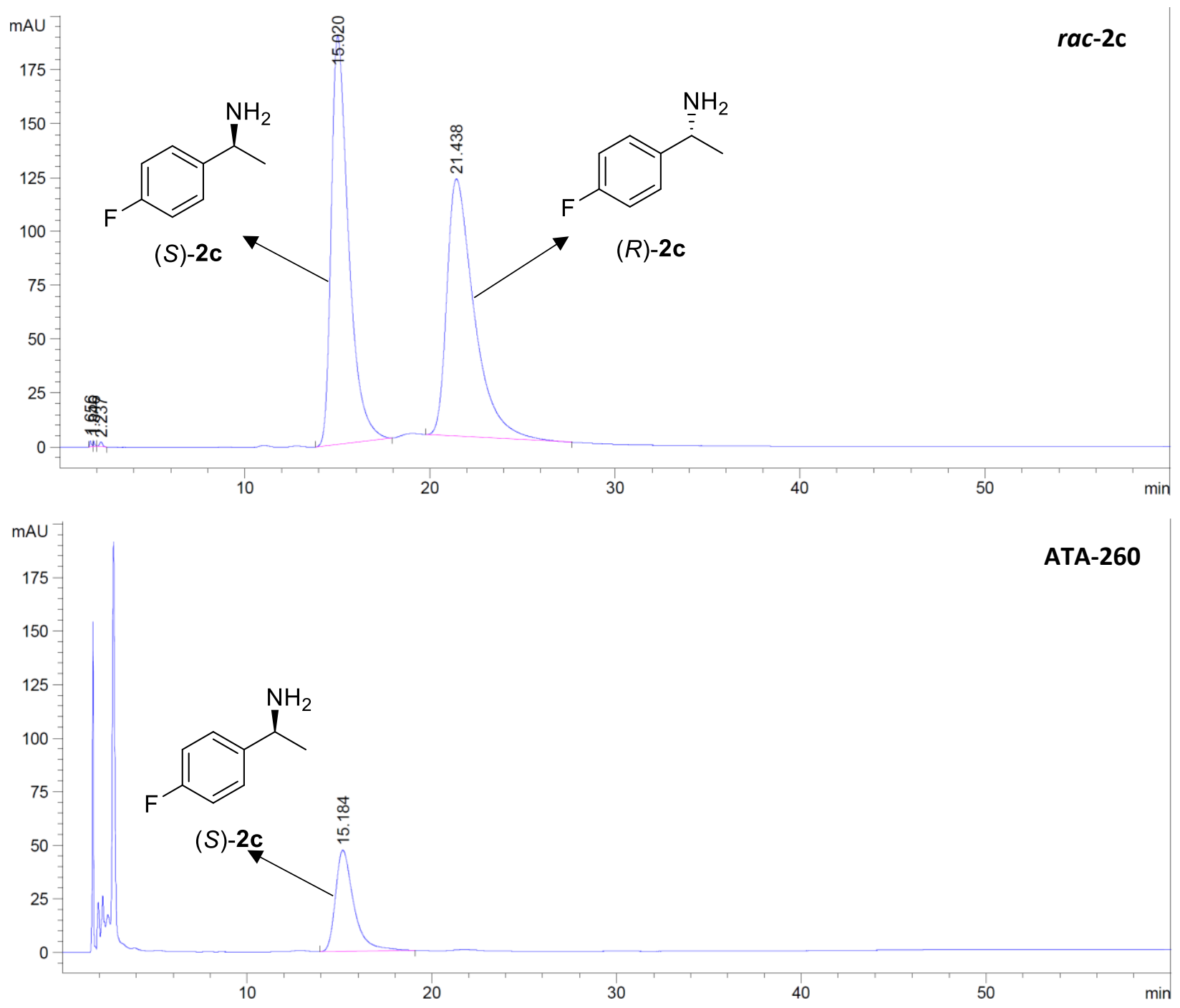


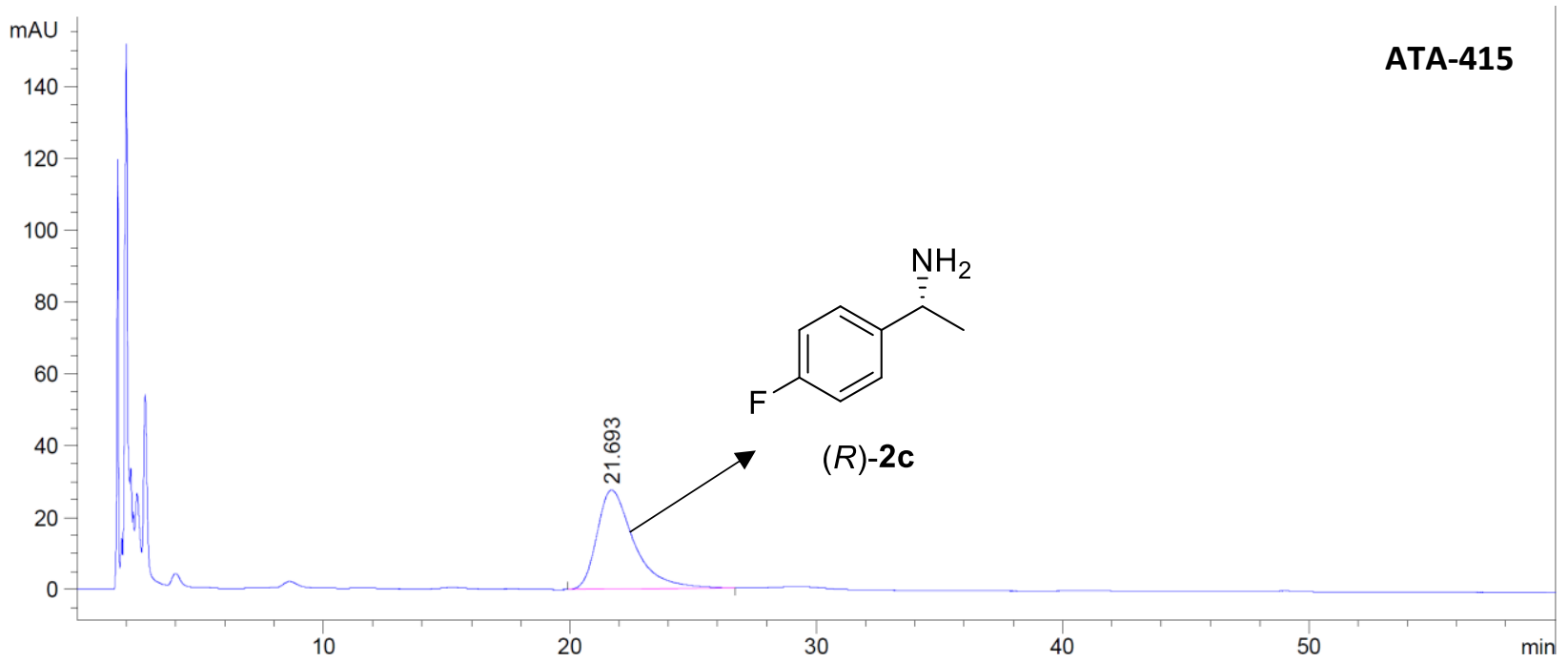

Chromatograms of $\mathbf{3 c}$
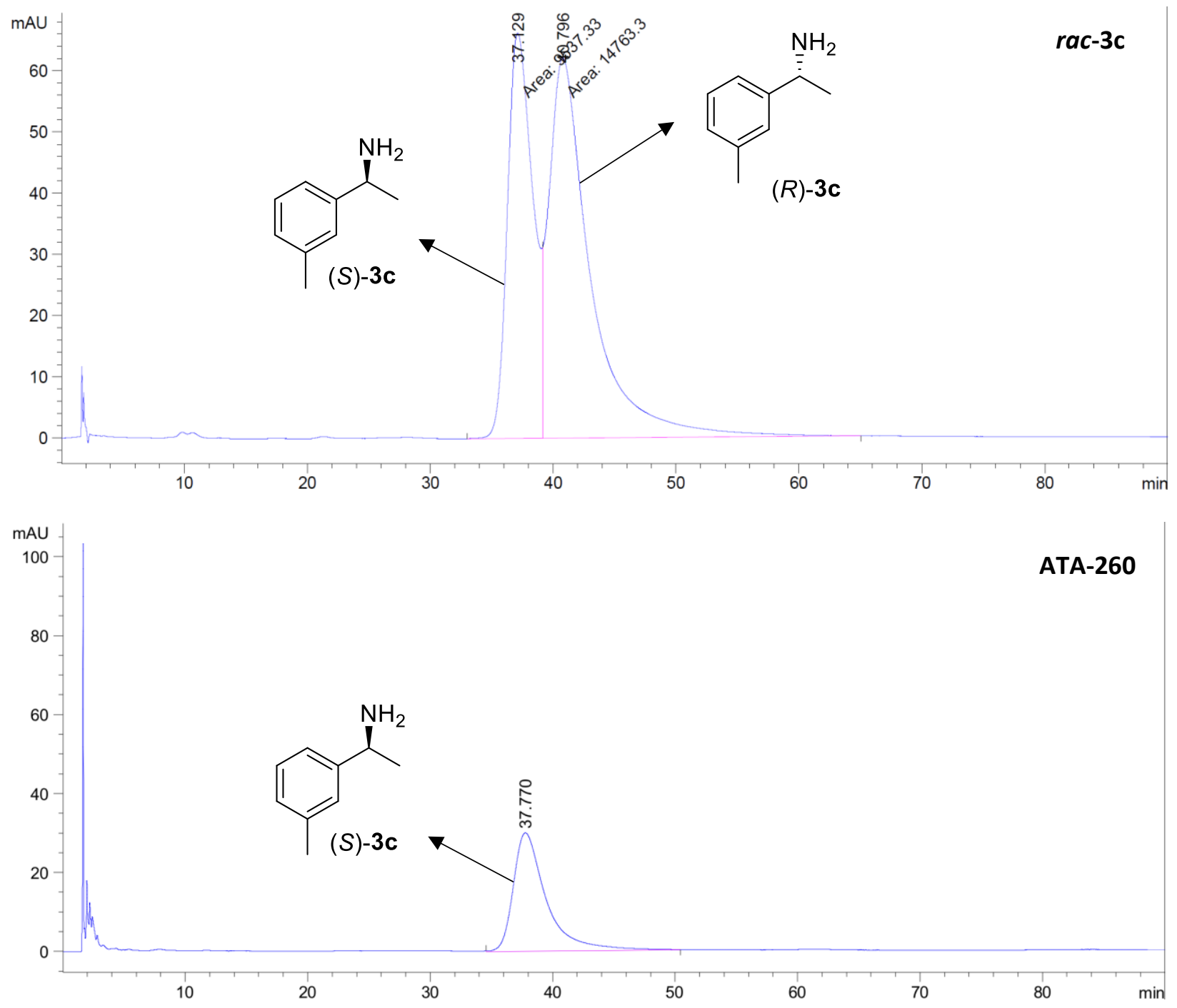


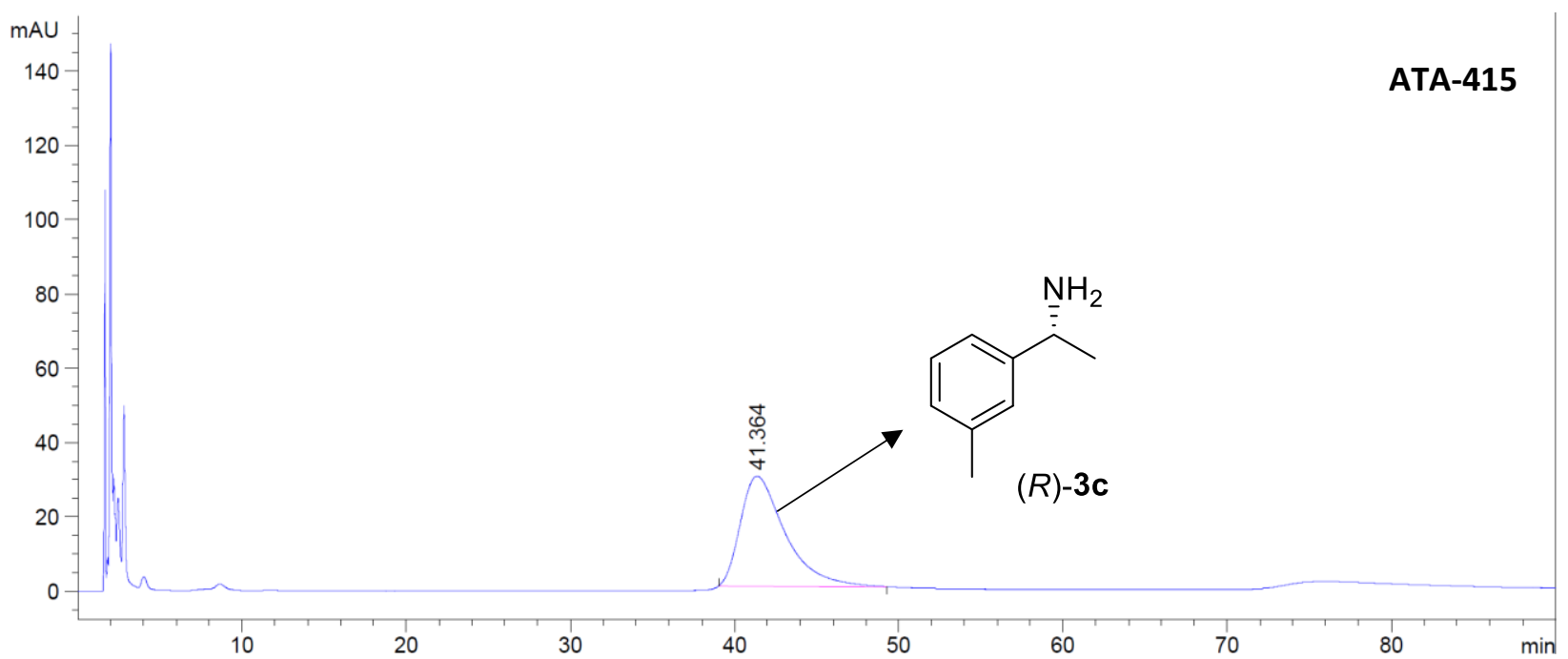

Chromatograms of $4 \mathrm{c}$
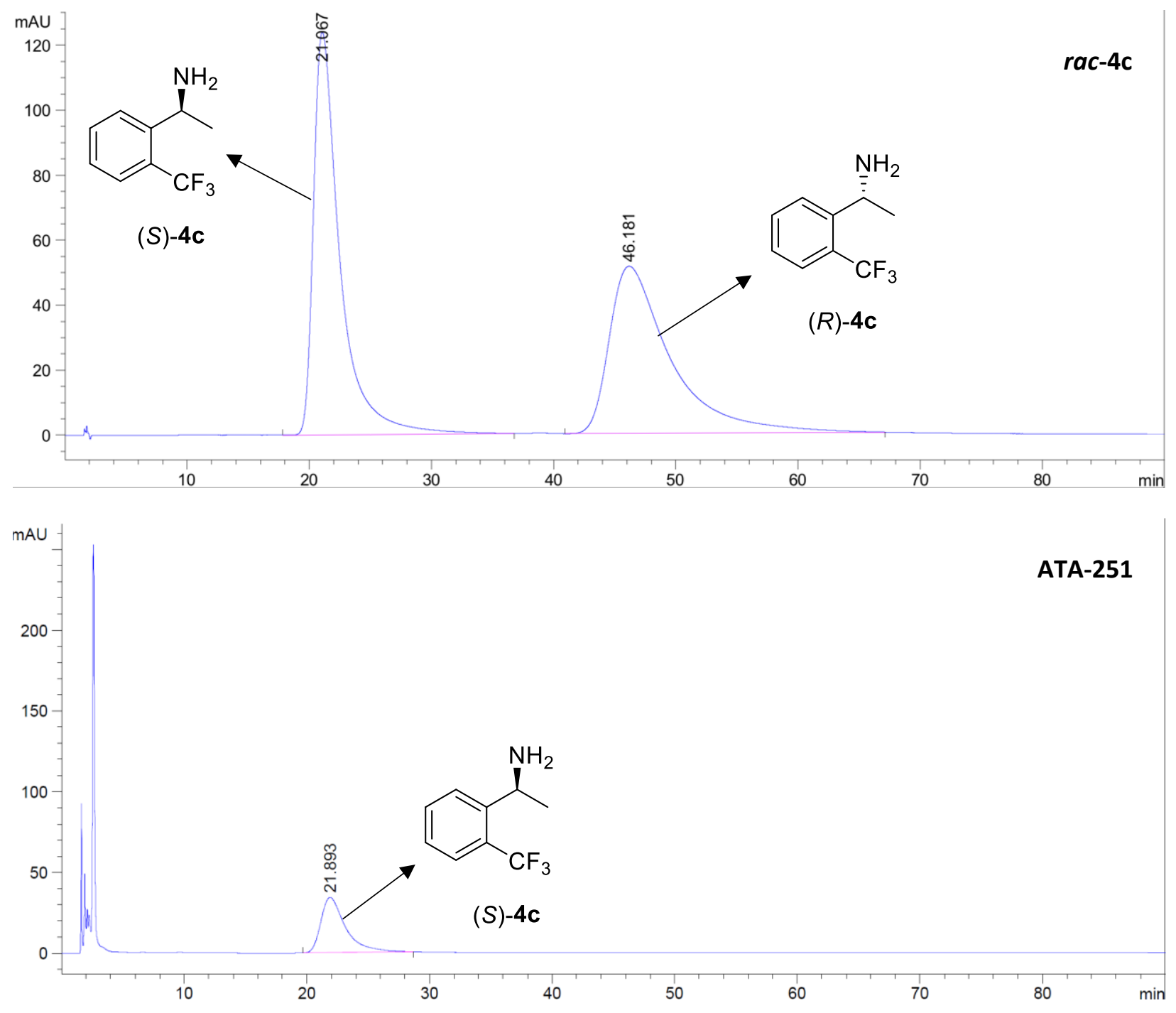

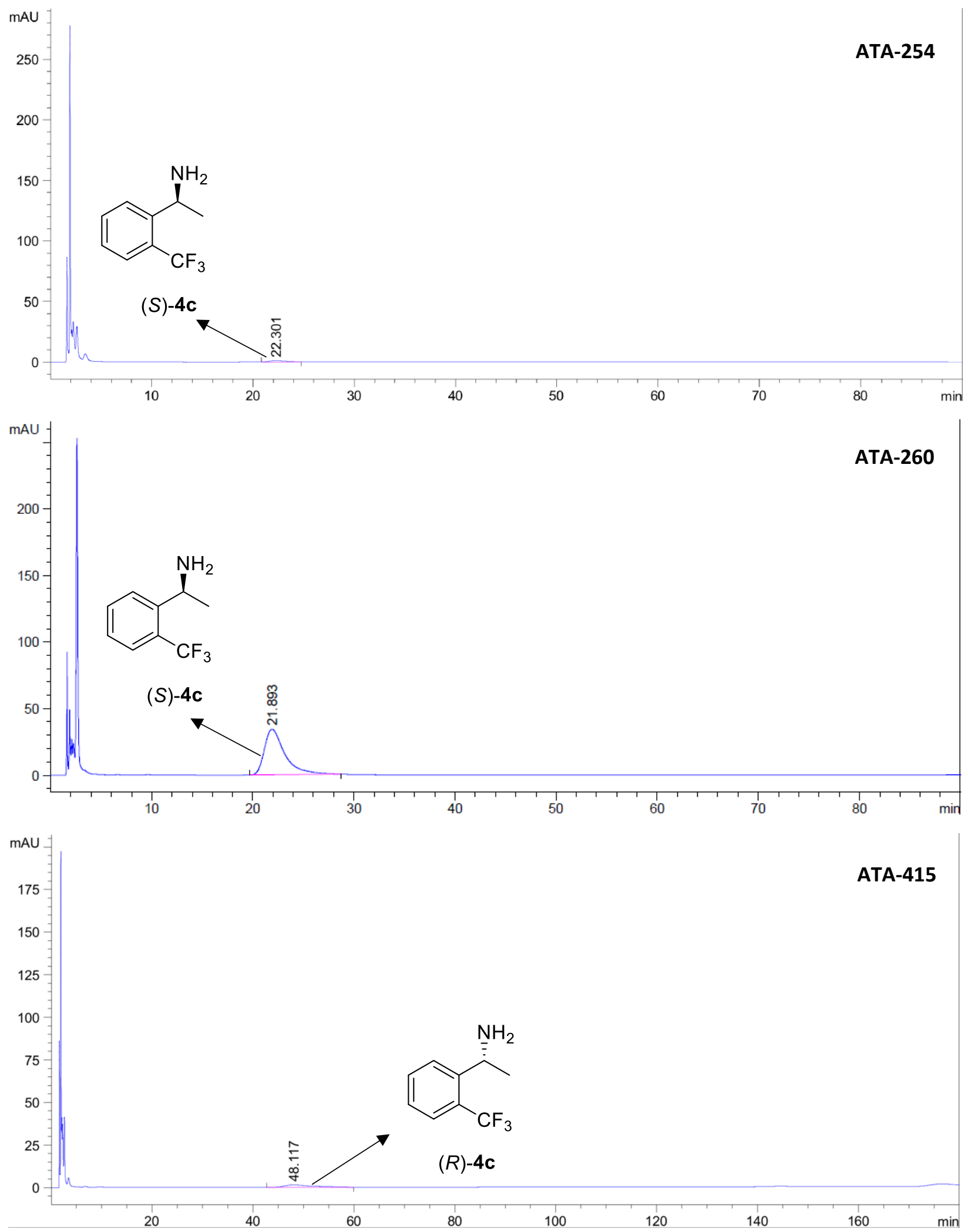
Chromatograms of $\mathbf{5 c}$
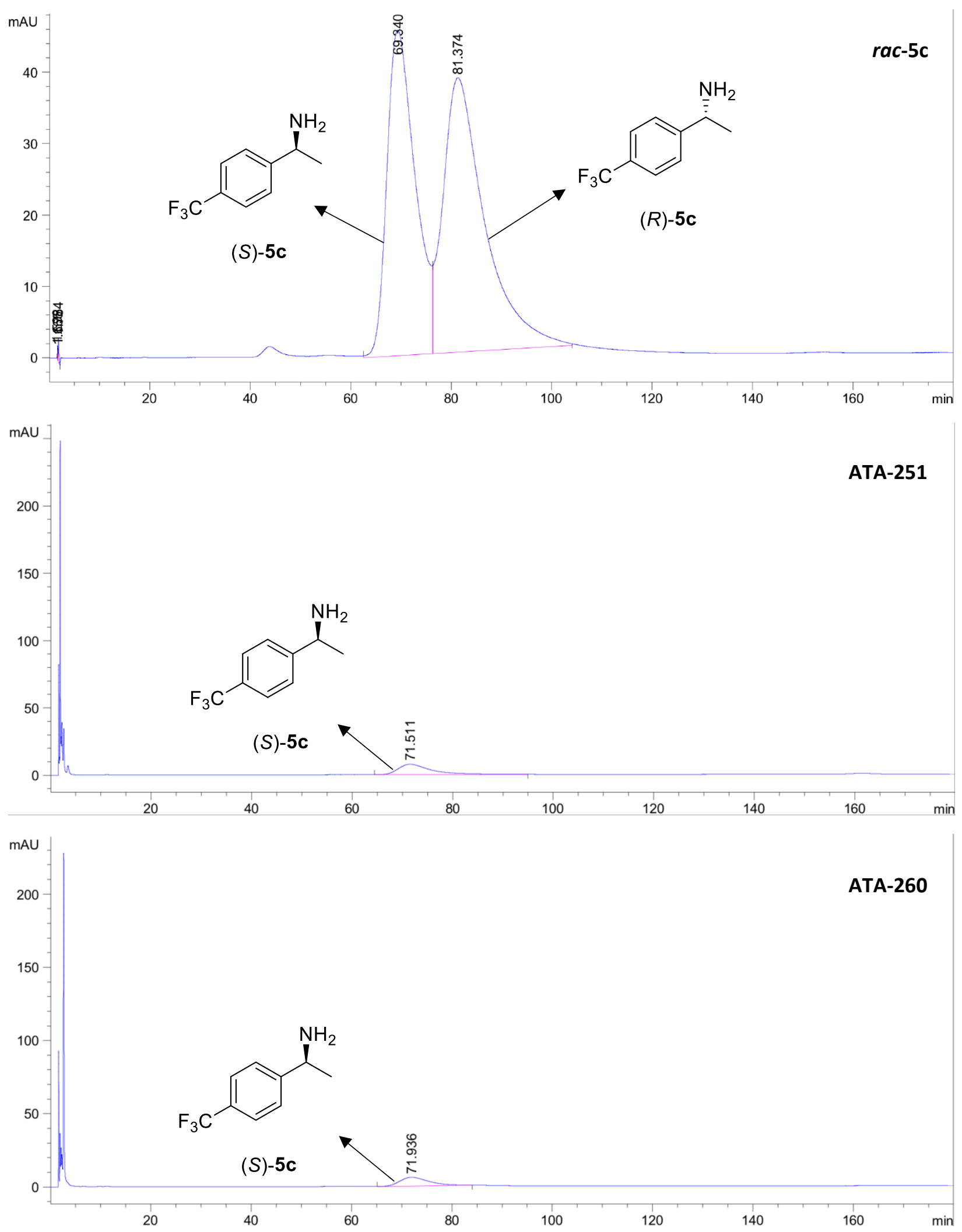


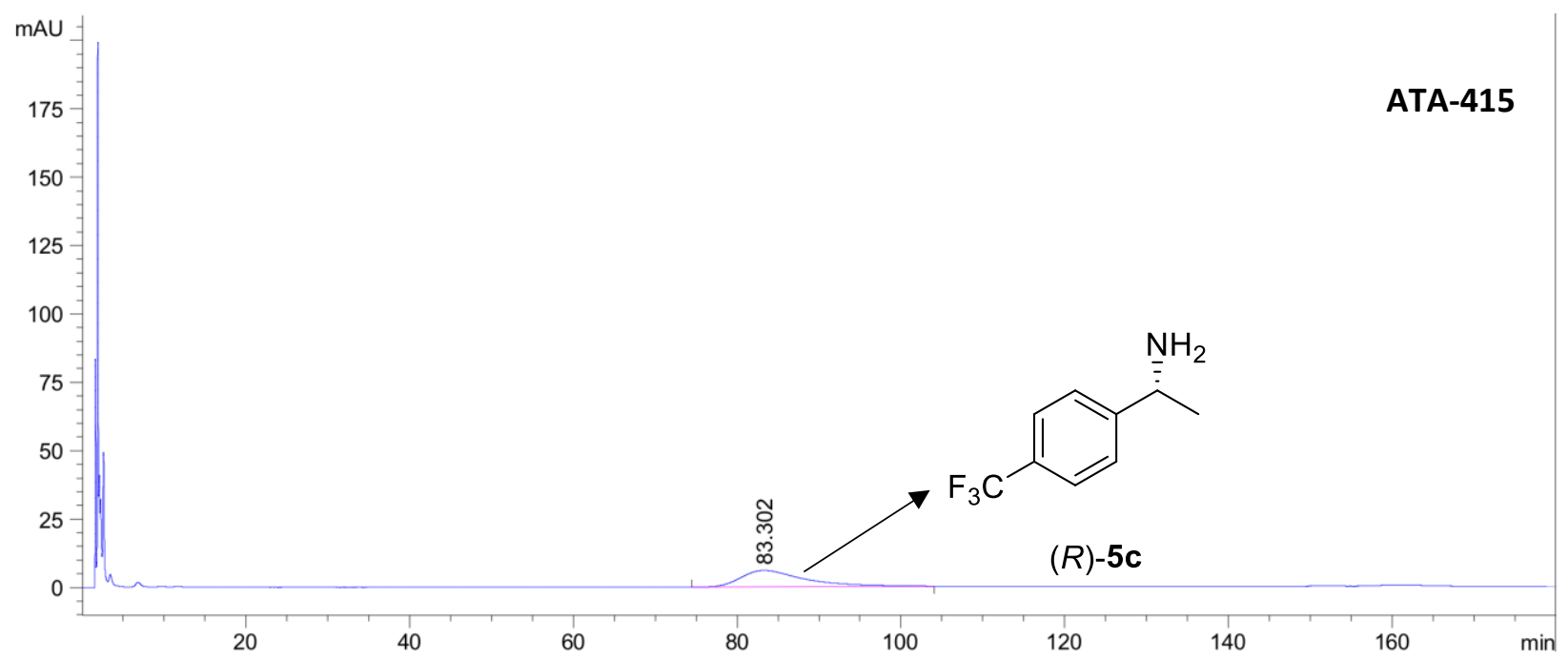

Chromatograms of $6 c$
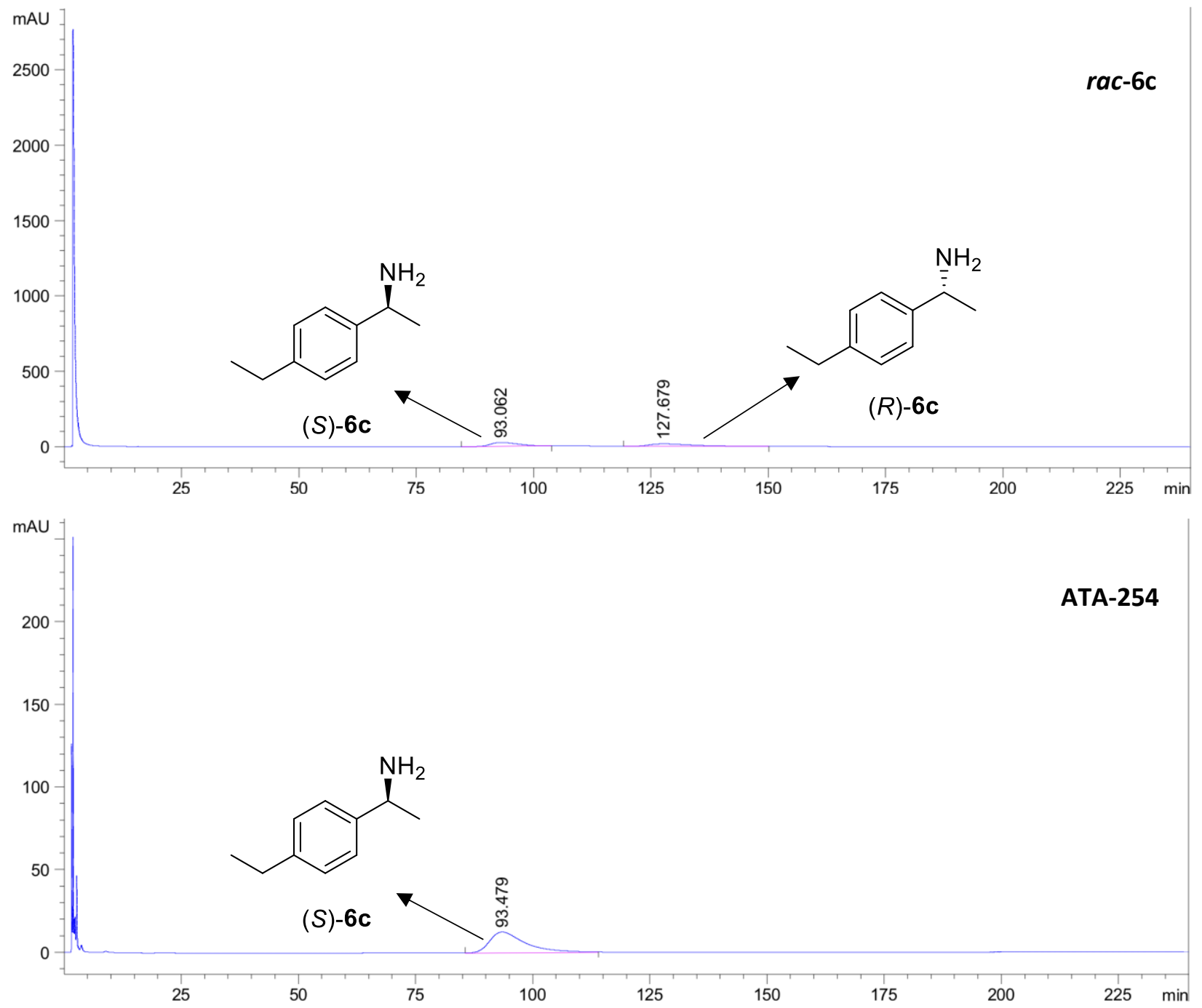

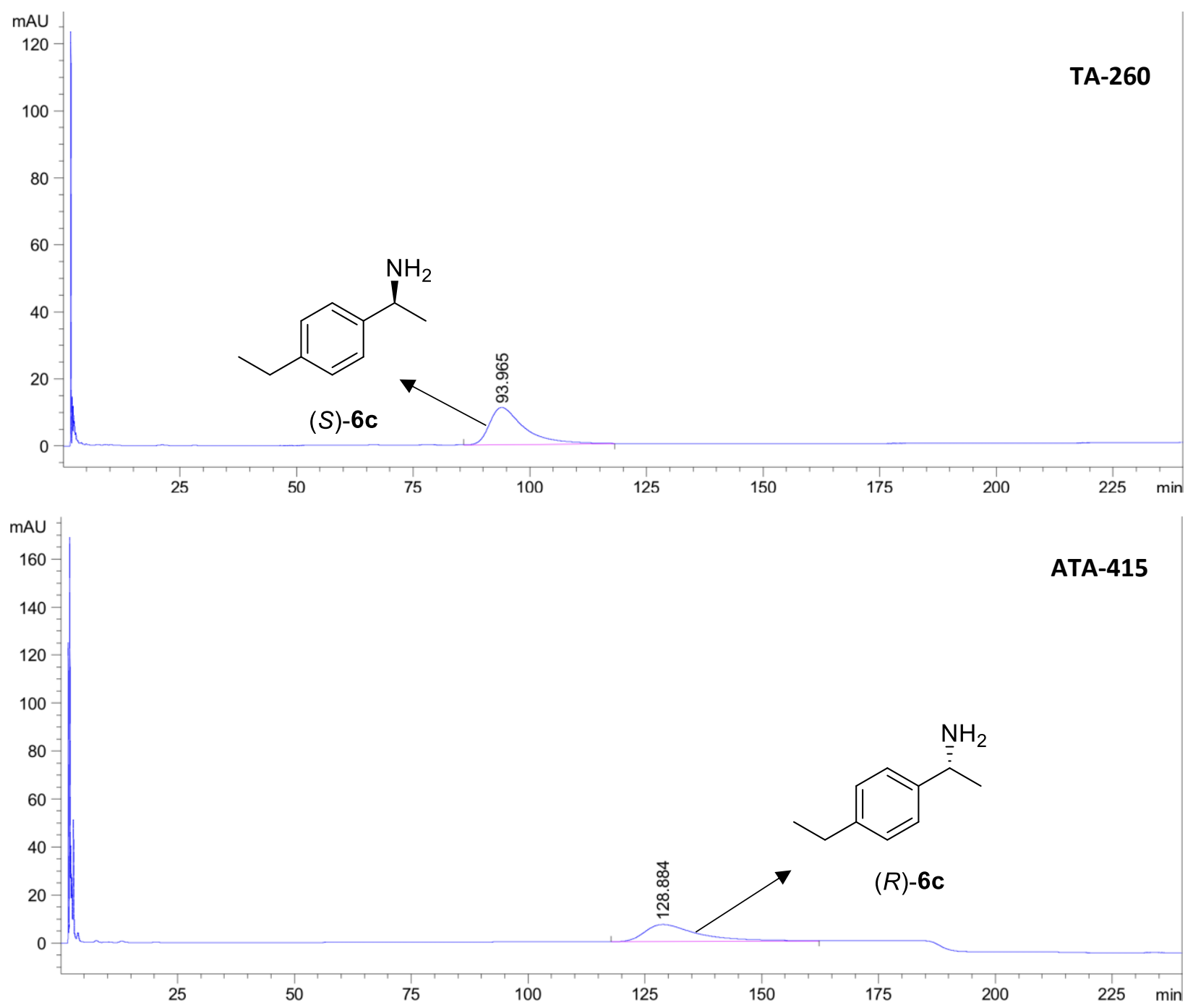

Chromatograms of 7c

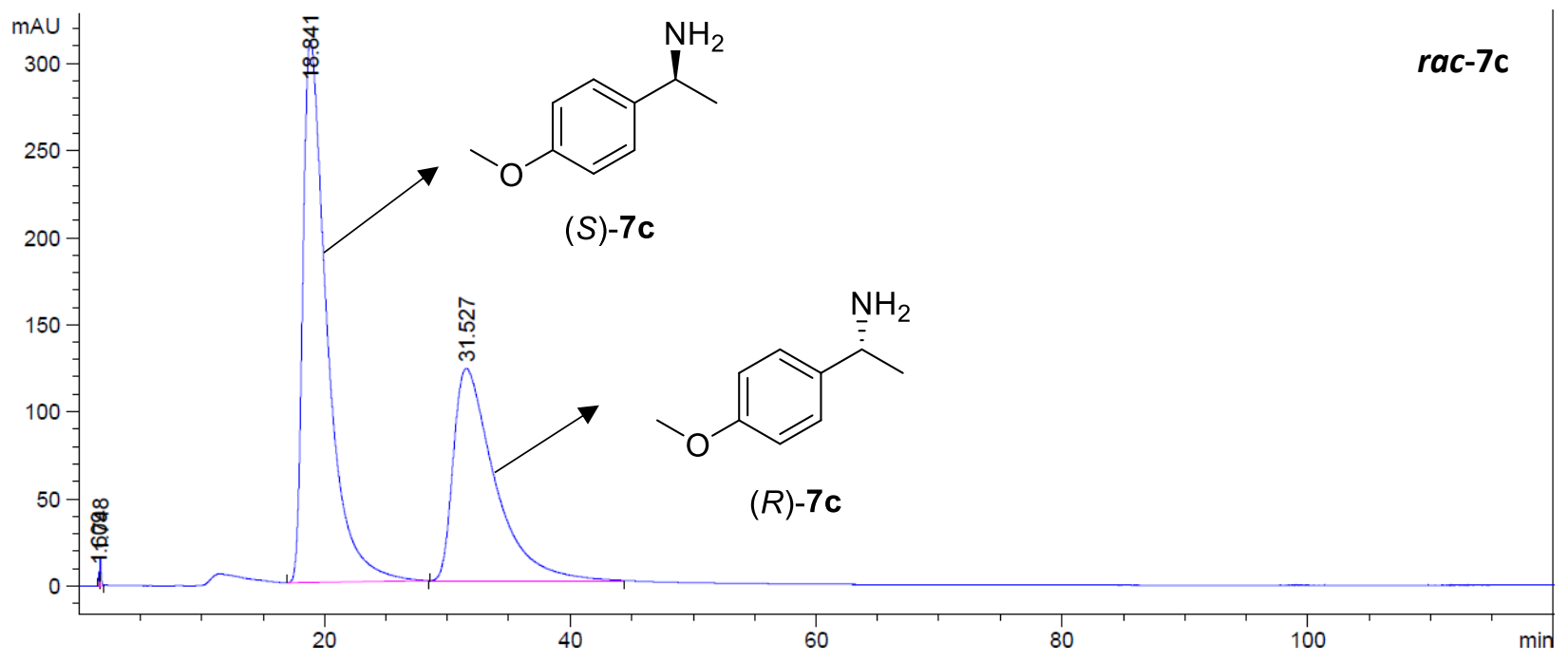



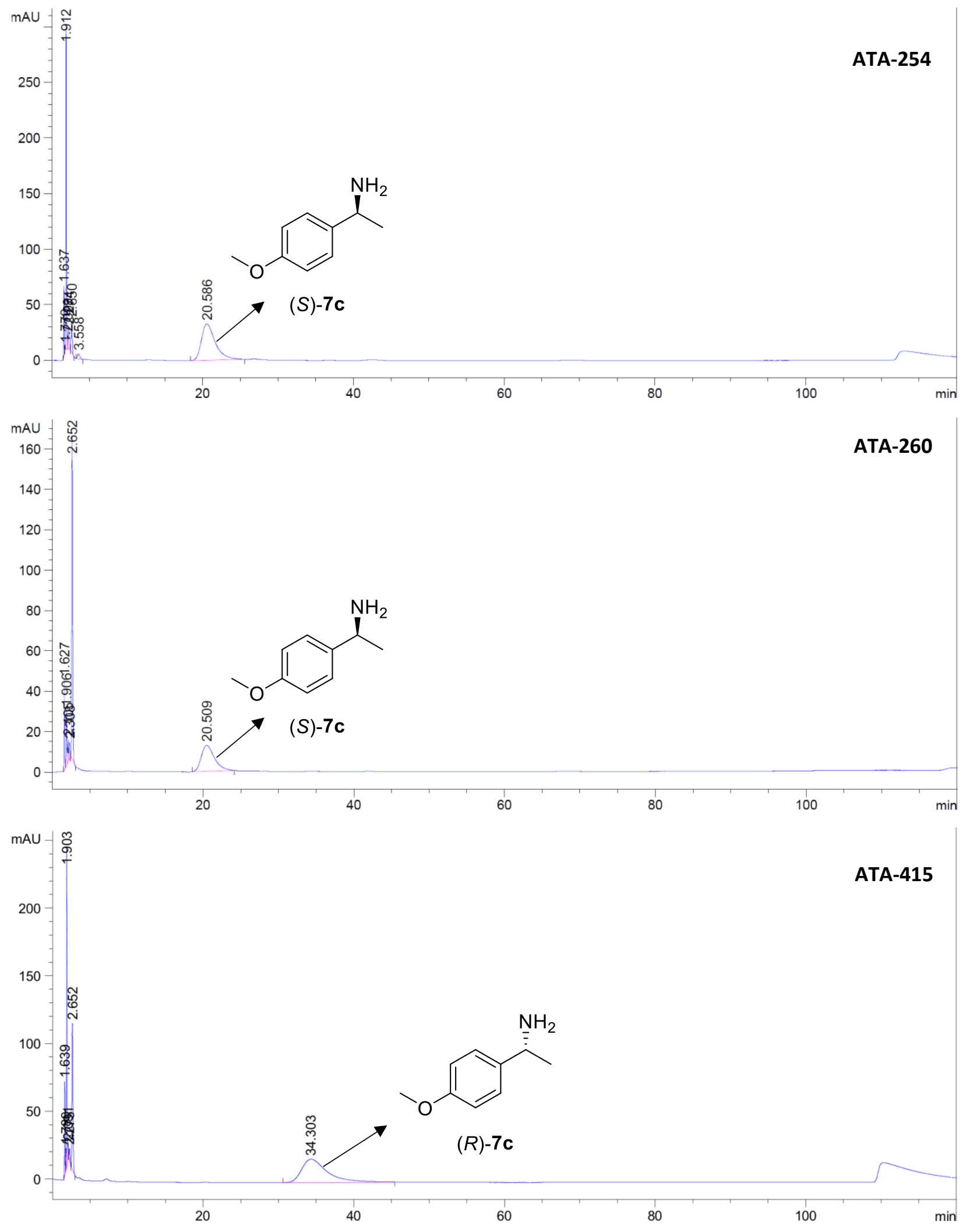
Chromatograms of $\mathbf{8 c}$
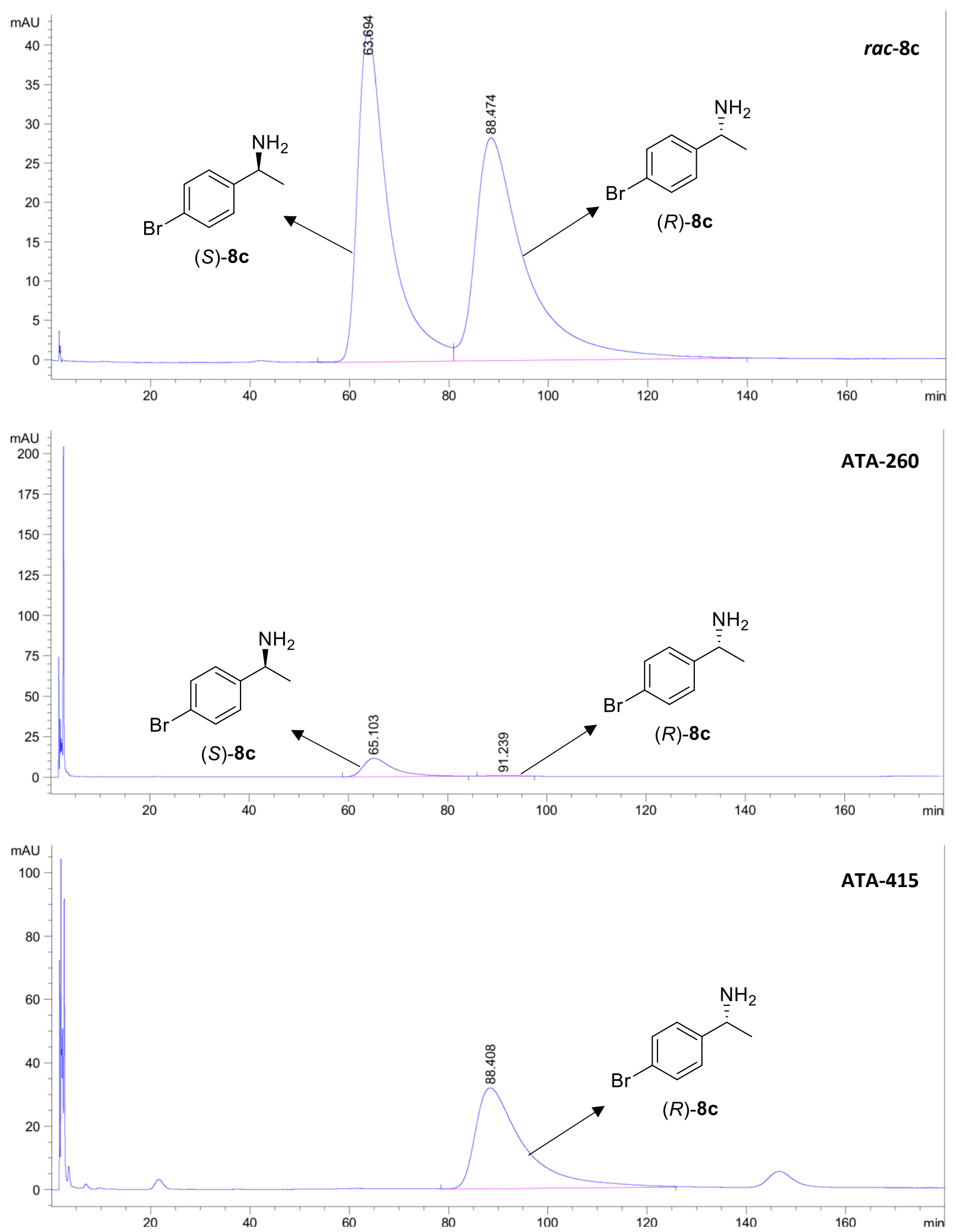
Chromatogram of preparative scale reaction 1c
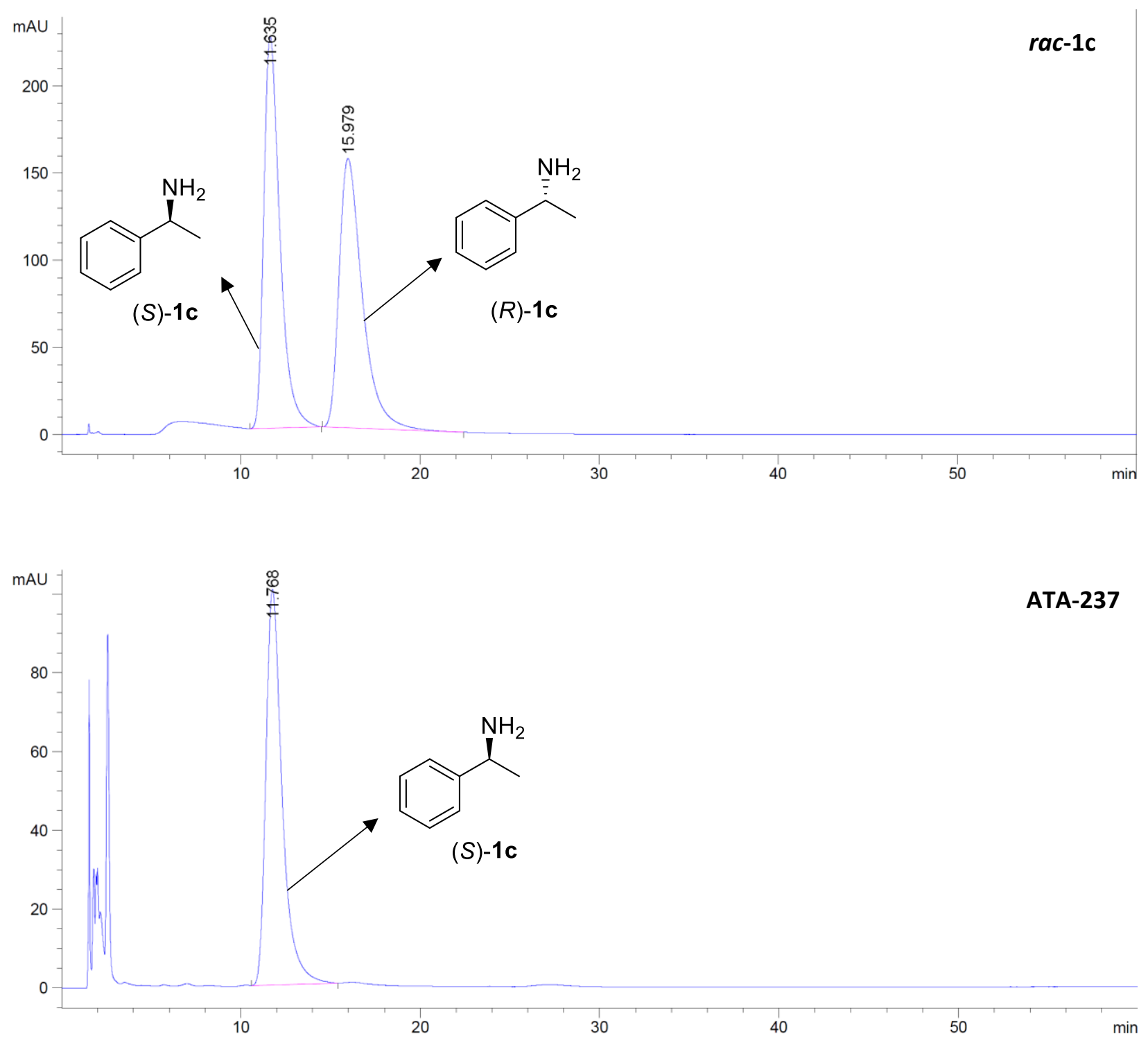
Chromatogram of preparative scale reaction 7c
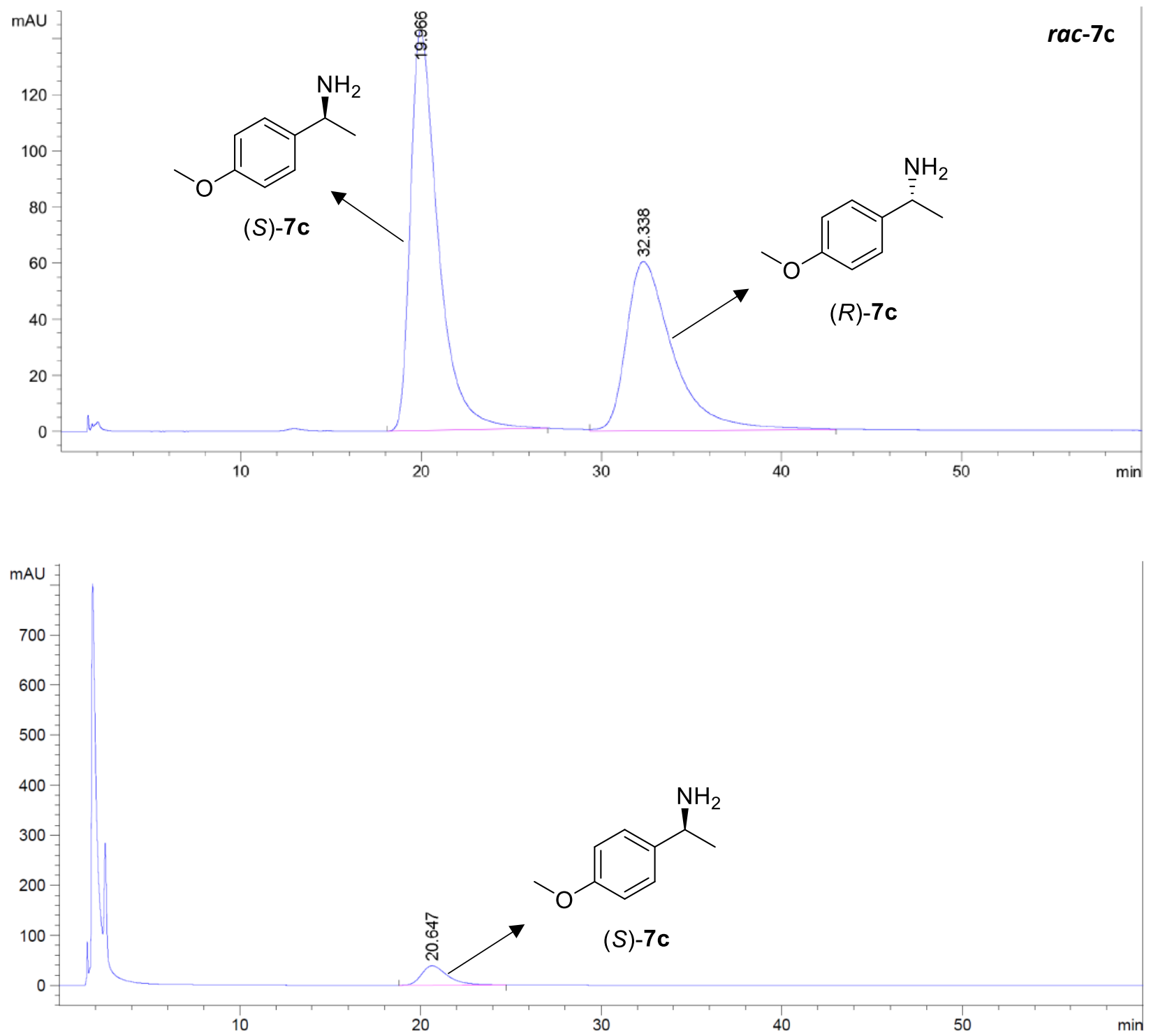
5.2 HPLC standard curves of amine products

HPLC standard curve of 1c

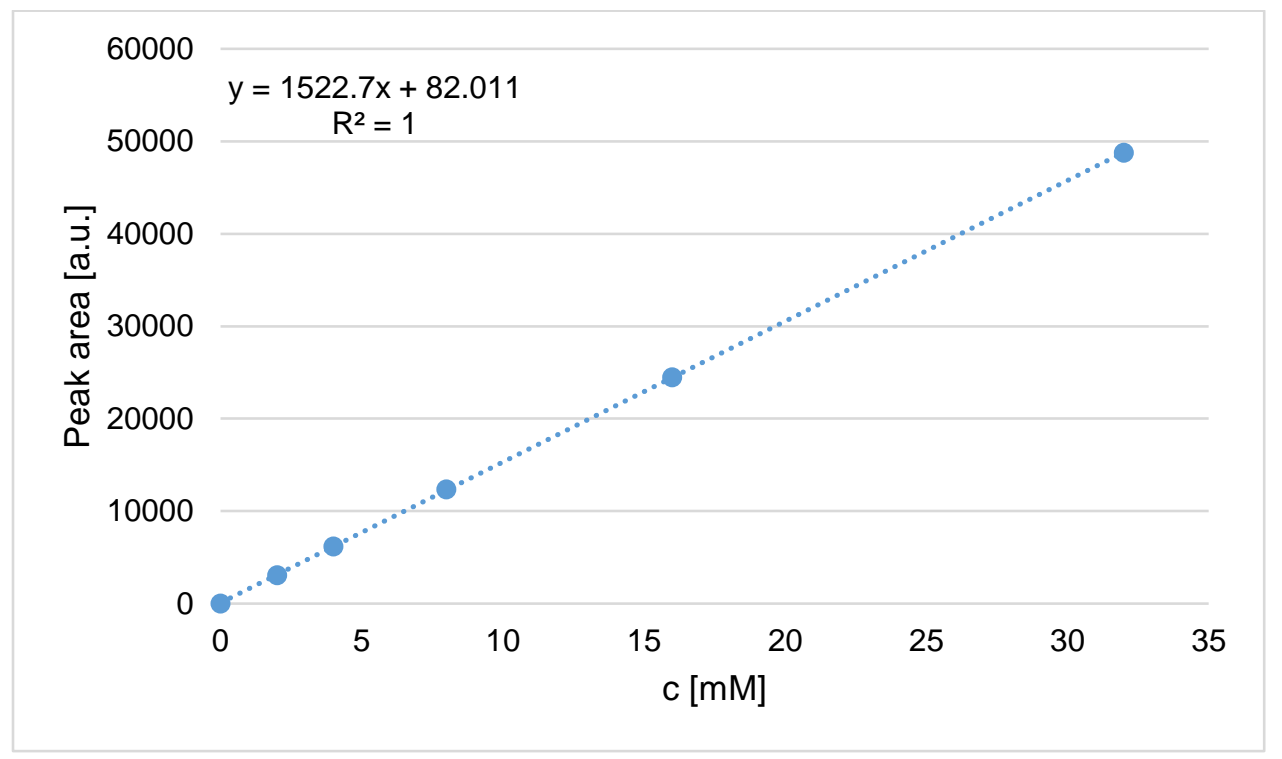

HPLC standard curve of 2c

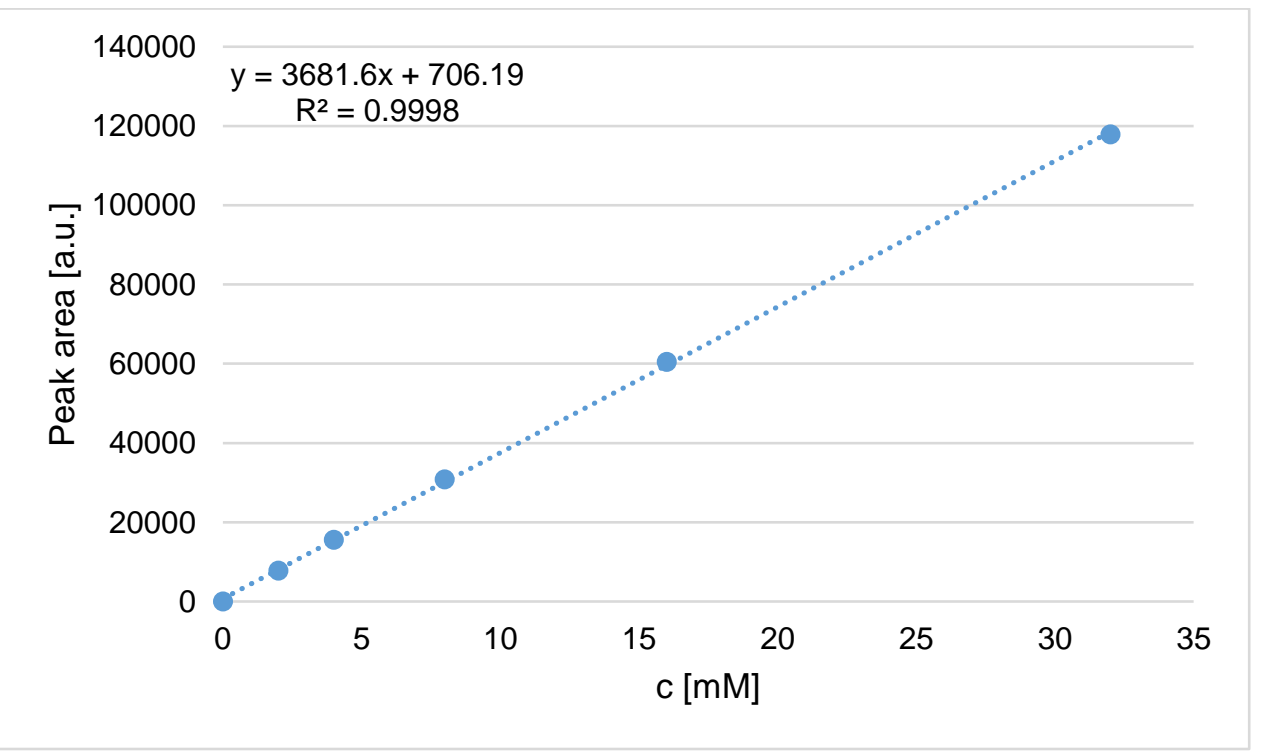




\section{HPLC standard curve of $\mathbf{3 c}$}

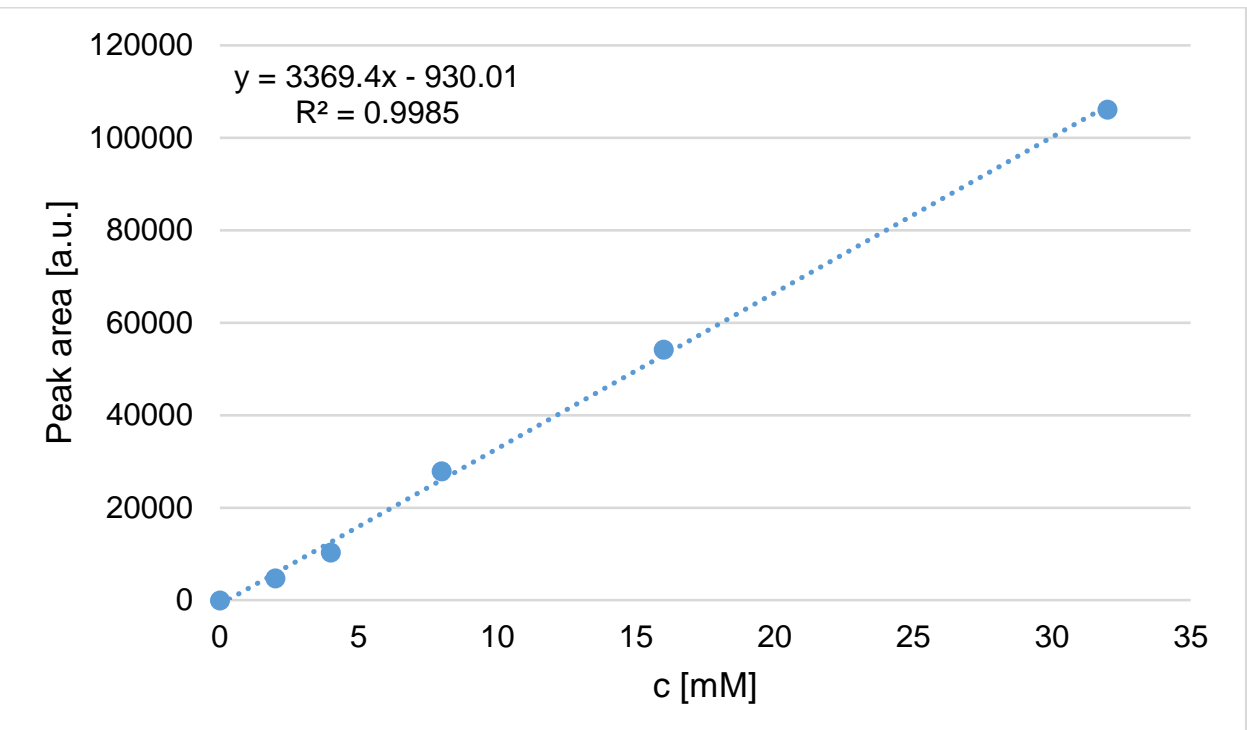

\section{HPLC standard curve of $\mathbf{4 c}$}

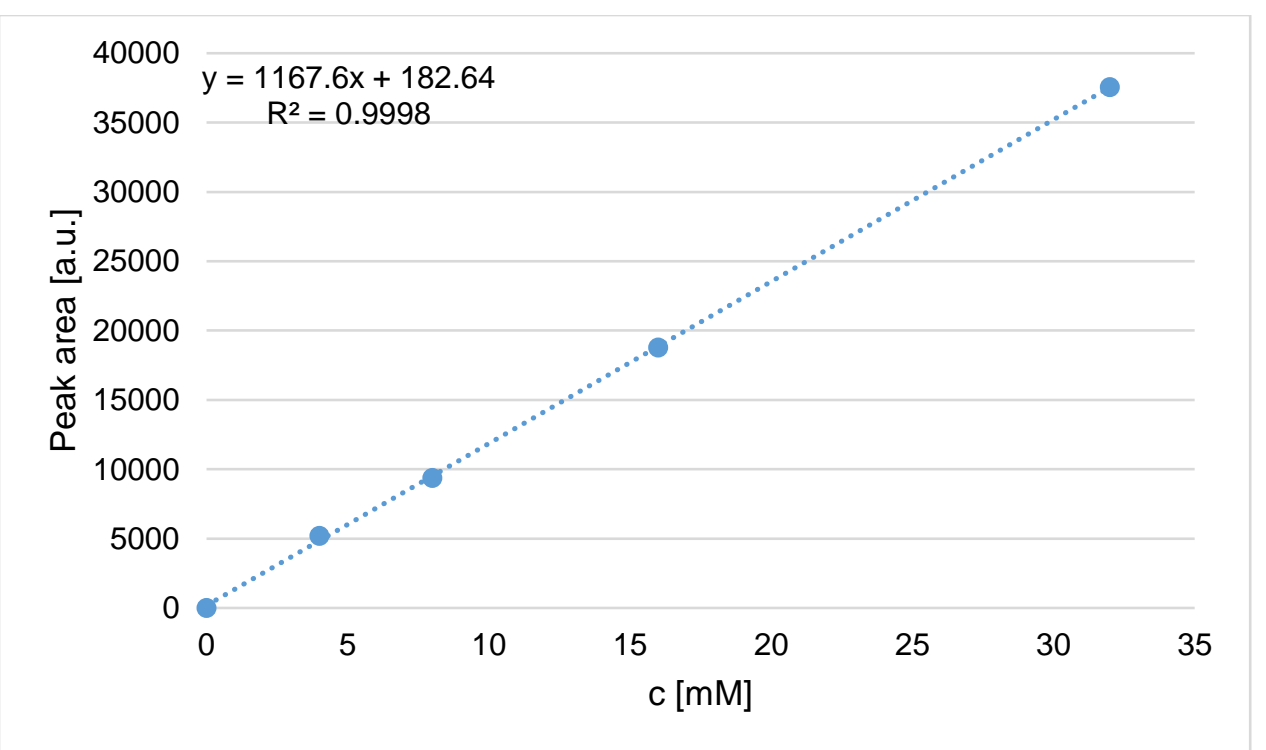




\section{HPLC standard curve of $5 c$}

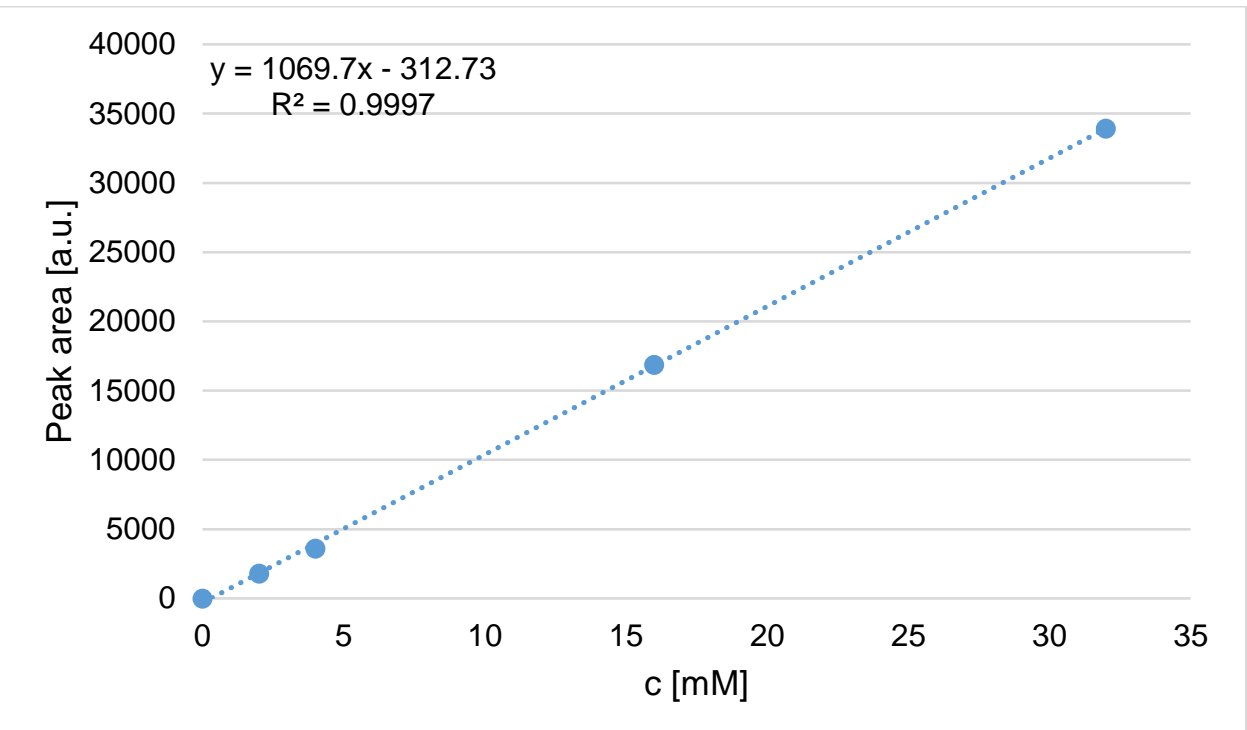

\section{HPLC standard curve of $6 c$}

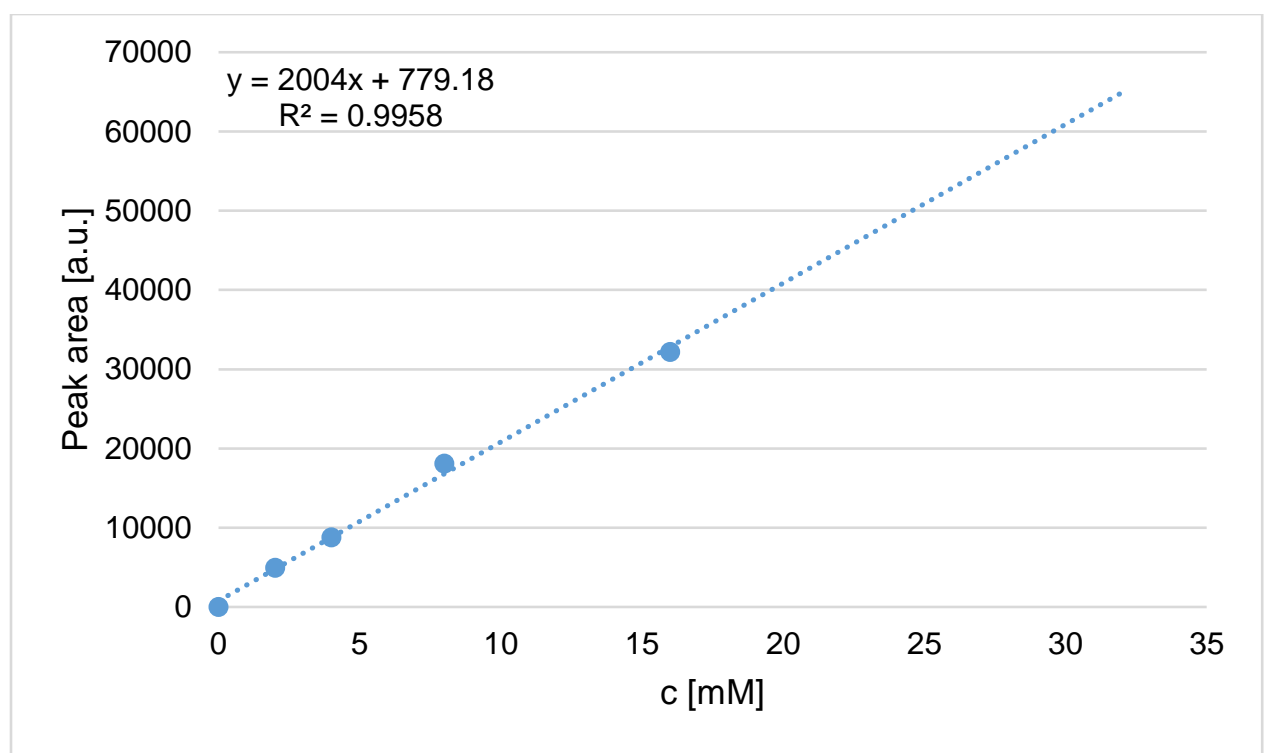




\section{HPLC standard curve of 7c}

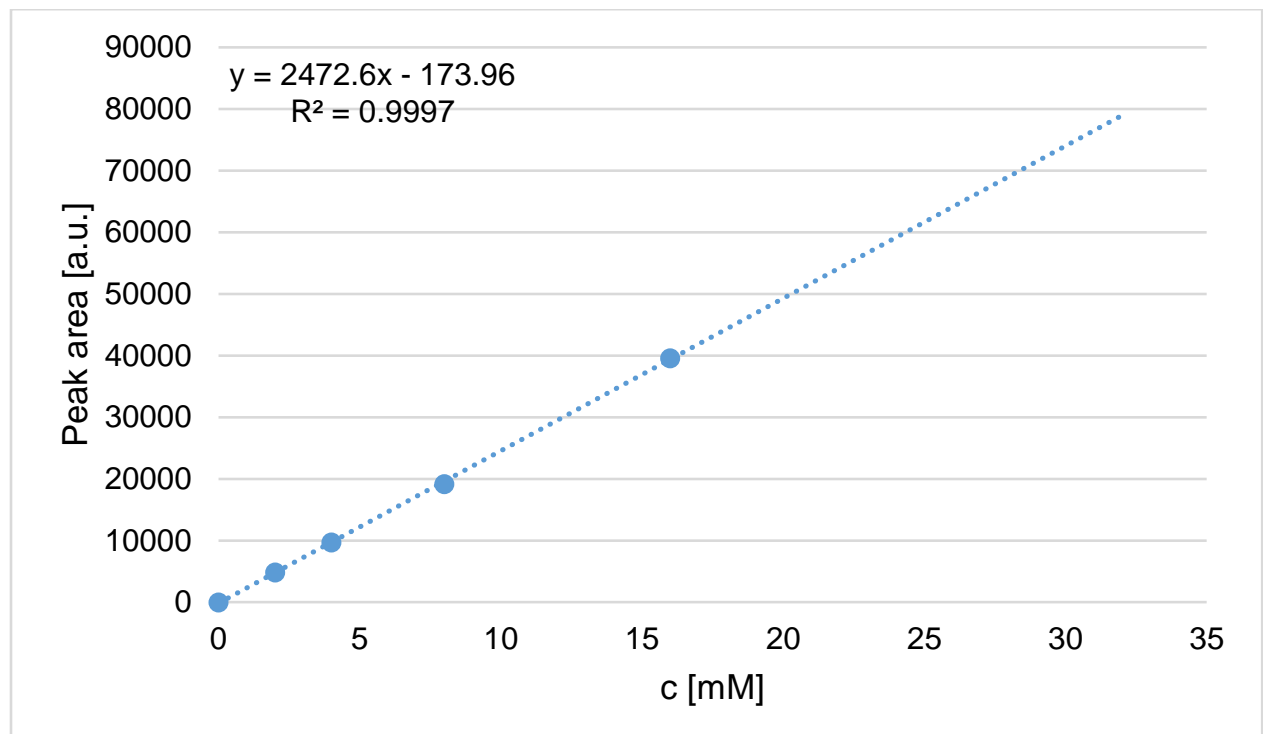

\section{HPLC standard curve of $\mathbf{8 c}$}

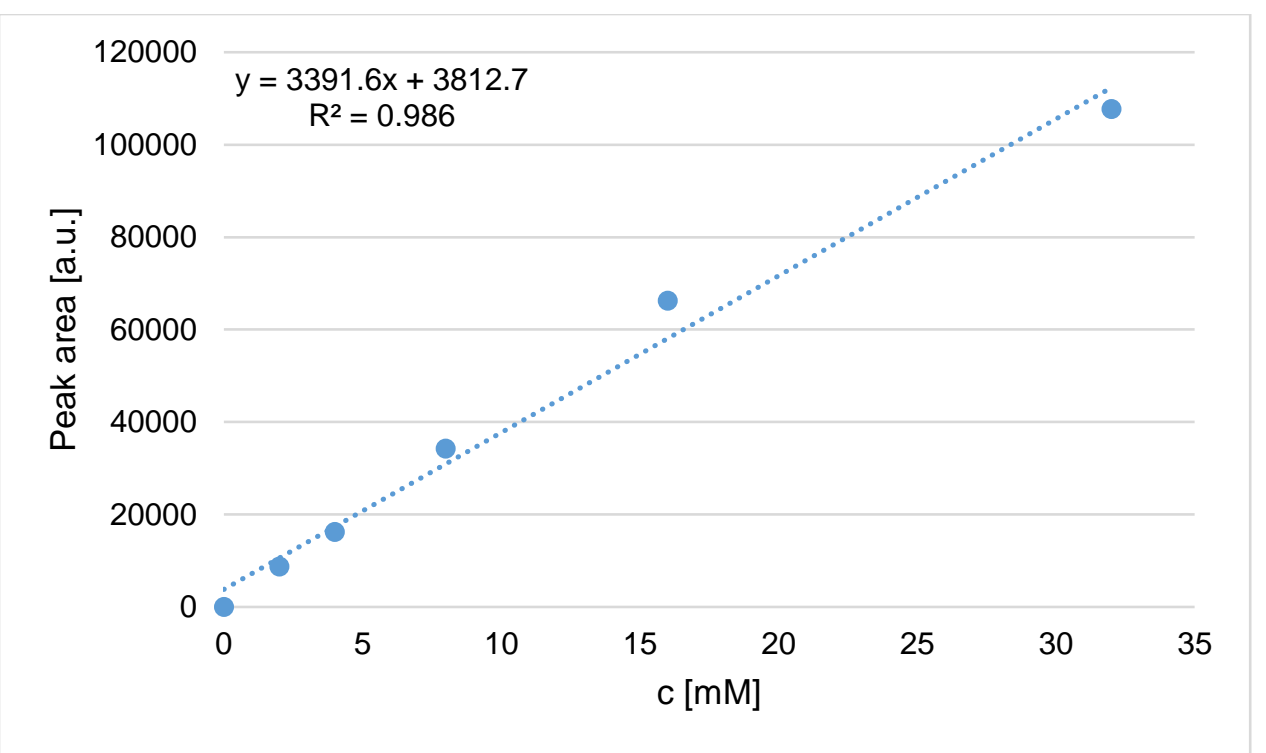




\section{NMR-spectroscopic data \& spectra}

\section{(S)-1-phenylethan-1-amine ((S)-1c) $)^{[3]}$}

${ }^{\mathrm{NH}_{2}}$ Colorless liquid, yield= 92\%; ${ }^{1} \mathrm{H}$ NMR $\left(500 \mathrm{MHz}, \mathrm{CDCl}_{3}\right) \delta 7.38-7.30(\mathrm{~m}, 1 \mathrm{H}), 7.27$

Me $-7.20(\mathrm{~m}, \mathrm{OH}), 4.12(\mathrm{q}, J=6.6 \mathrm{~Hz}, \mathrm{OH}), 1.39(\mathrm{~d}, J=6.7 \mathrm{~Hz}, 1 \mathrm{H}) .{ }^{13} \mathrm{C} \mathrm{NMR}(126 \mathrm{MHz}$, $\left.\mathrm{CDCl}_{3}\right) \delta 147.94,128.62,126.94,125.81,51.47,25.81$.

(S)-1-(4-methoxyphenyl)ethan-1-amine ((S)-7c) ${ }^{[4]}$

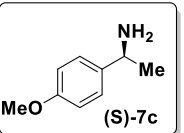

Colorless liquid, yield= 59\%; ${ }^{1} \mathrm{H}$ NMR $\left(500 \mathrm{MHz}, \mathrm{CDCl}_{3}\right) \delta 7.27(\mathrm{~d}, J=7.0 \mathrm{~Hz}, 2 \mathrm{H})$, $6.87(\mathrm{~d}, J=8.7 \mathrm{~Hz}, 2 \mathrm{H}), 4.09(\mathrm{q}, J=6.6 \mathrm{~Hz}, 1 \mathrm{H}), 3.80(\mathrm{~s}, 3 \mathrm{H}), 1.81(\mathrm{~s}, 2 \mathrm{H}), 1.37$ (d, $J=6.6 \mathrm{~Hz}, 3 \mathrm{H}) .{ }^{13} \mathrm{C}$ NMR $\left(126 \mathrm{MHz}, \mathrm{CDCl}_{3}\right) \delta 139.77,126.92,113.97,55.43,50.84$, 25.71 

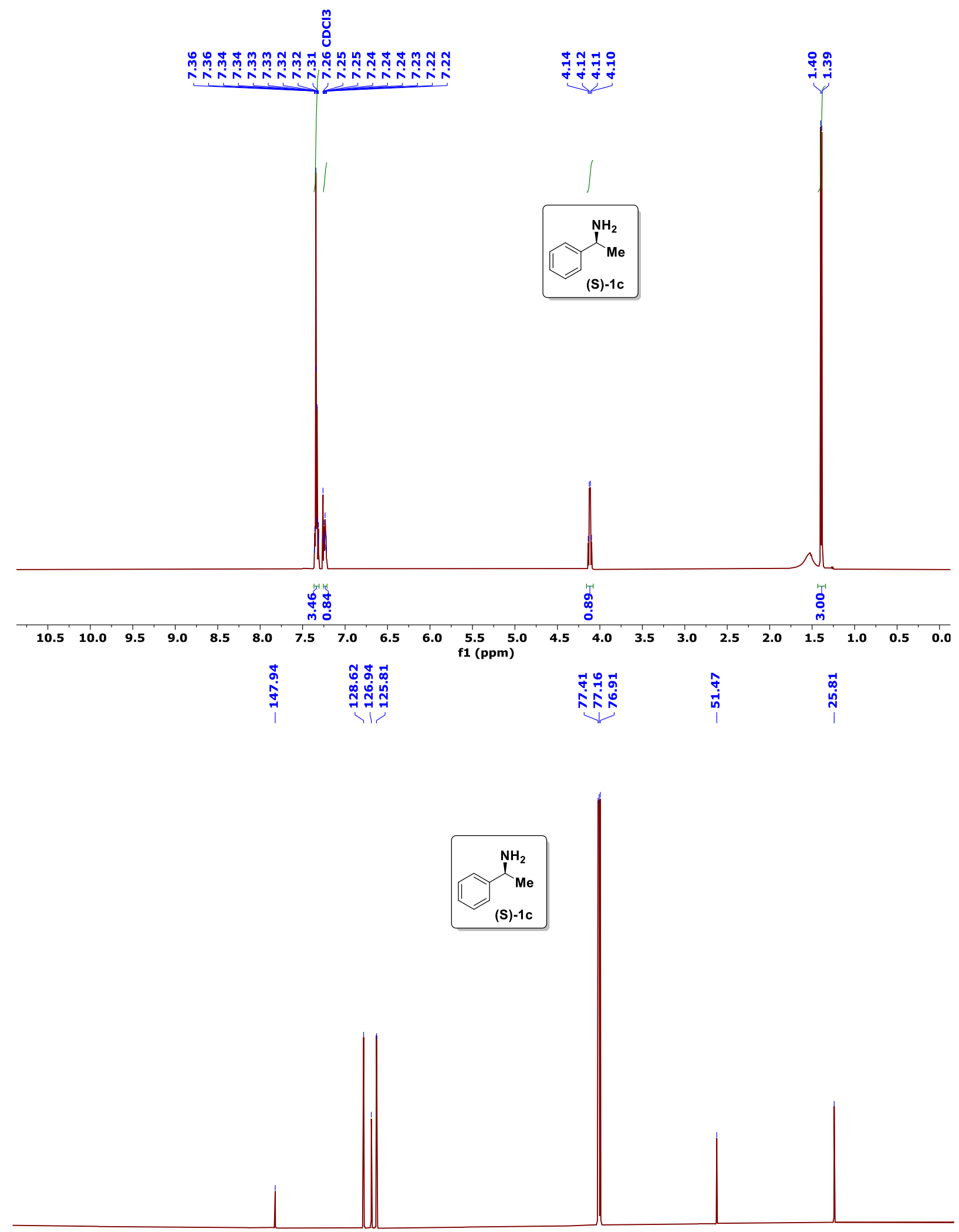

$\begin{array}{llllllllll}200 & 190 & 180 & 170 & 160 & 150 & 140 & 130 & 120 & 110 \\ \text { f1 (ppm) }\end{array}$ 

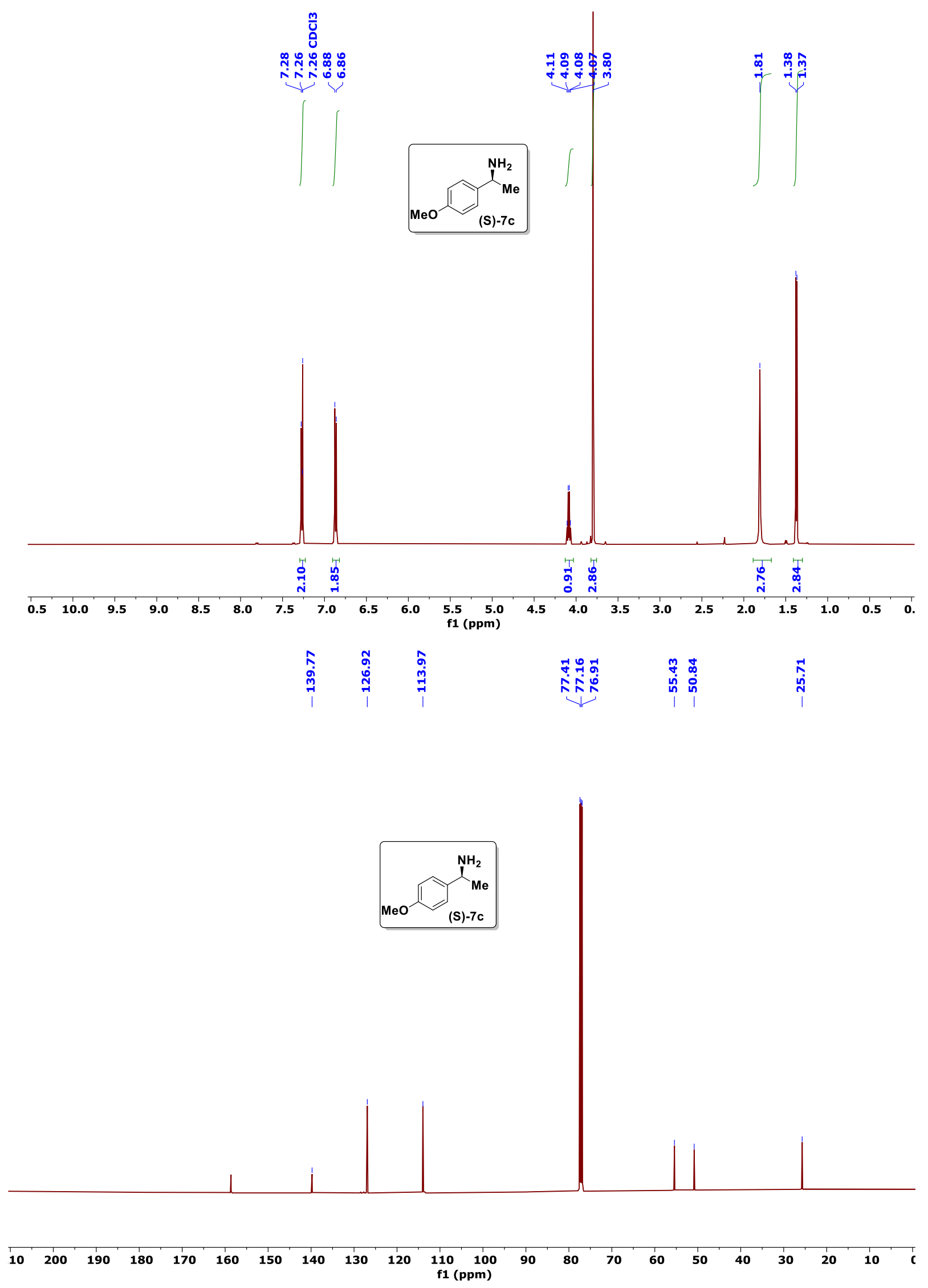


\section{References}

1 Das, A. K.; Park, S.; Muthaiah, S.; Hong, S. H., Ligand- and Acid-Free Gold(I) Chloride Catalyzed Hydration of Terminal Alkynes. Synlett 2015, 26, 2517-2520.

Shin, G.; Mathew, S.; Shon, M.; Kim, B-G; Yun, H., One-pot one-step deracemization of amines using $\omega$-transaminases. Chem. Commun. 2013, 49, 8629-8631.

3 Atobe, M.; Yamazaki, N.; Kibayashi, C., Enantioselective Synthesis of Primary 1-(Aryl)alkylamines by Nucleophilic 1,2-Addition of Organolithium Reagents to Hydroxyoxime Ethers and Application to Asymmetric Synthesis of GProtein-Coupled Receptor Ligands. J. Org. Chem. 2004, 69, 5595-5607.

4 Guijarro, D.; Pablo, O.; Yus, M. J. Asymmetric Synthesis of Chiral Primary Amines by Transfer Hydrogenation of N(tert-Butanesulfinyl)ketimines. Org. Chem. 2010, 75, 5265-5270. 